\title{
Prentice G. Downes's Eastern Arctic Journal, 1936
}

\author{
Edited and introduced by R.H. COCKBURN ${ }^{1}$
}

\begin{abstract}
The first of a chronological series of northern journals by a man who later did mapping that was put to use by the Dominion government and who was to write one of this century's most perceptive books about the subarctic north and wilderness canoe travel. The journal provides a detailed account of P. G. Downes's experiences during R.M.S. Nascopie's 1936 passage from Montréal to Churchill.
\end{abstract}

Key words: Nascopie, Eastern Arctic, Eskimos, William Gibson, David A. Nichols, Nicholas Polunin, geology, Churchill

RESUMÉ. Voici le premier d'une série chronologique de journaux d'un homme qui dessina plus tard des cartes qui furent utilisées par le gouvernement du Dominion et qui devait ecrire un des livres les plus perceptifs du siècle su le nord sub-arctique et les voyages en canoe en terre sauvage. Le journal présente un compte-rendu détaillé des expériences de P.G. Downes au cours du voyage du R.M.S. Nascopie entre Montréal et Churchill en 1936.

Mots clés: Nascopie, est de l'Arctique, Esquimaux, William Gibson, David A. Nichols, Nicholas Polunin, géologie, Churchill

Traduit pour le journal par Maurice Guibord.

\section{INTRODUCTION}

At the beginning of 1936, Prentice Downes, age 25, was in the middle of his third year as a teacher of Latin, science, and history at Belmont Hill School on the western outskirts of Boston. Early that January Downes went in to 447 Marlborough Street to meet and question the redoubtable Labrador traveller William Brooks Cabot, by then in his 78th year, and afterward recorded in his diary that "I visited him on Sunday afternoon and he talked for five hours. Told me the real story on the Wallace-Hubbard business. Also much interesting information. Suggests I make a trip to Reindeer Lake to look for the Inland Eskimos." Not until the summer of 1939 would Downes, at the end of a long and arduous trip by canoe, meet the Caribou Eskimos at Windy Lake, N.W.T., but Cabot's recollections and encouragement were a spur to him and reinforced northern yearnings that were already strong.

For Downes was an ardent student of the history and geography of the North, and by 1936 had accumulated a large personal library of northern books. He had spent the preceding July on the North Shore of the St. Lawrence, salmon-fishing with Napoleon Comeau's son Edgar, absorbing the lore of that coast and its interior, and visiting with Montagnais Indians. By 25 January, a few days after his meeting with Cabot, he was purchasing "Brit. Ad. chart $\mathbf{3 7 5}$ of Hamilton Inlet to Nain" and "thinking about a new summer route. Diamond [Dead Diamond River, New Hampshire] - Clarke City - and then taking Nascopie around to Churchill. Back by train. This would be a wonderful large-scale survey trip of [the] country, and I might get some very worthwhile information as a basis for further reconnoitering....Must get in touch with H.B. Co. and see when the Nascopie sails this year." Downes, as the diary reveals, was both lonely and dissatisfied with teaching at this time. His entry of 3 February illustrates not only his fascination with the north, but also his determination to escape to it: "Skipped off today to... Widener [Harvard's library] to return the long-lost book [Dillon Wallace's Lure of the Labrador Wild] and Hind's Explorations in the Labrador
Peninsula. Got autobiography of Klengenberg and ordered Ingstad's Land of Feast and Famine. I have read the latter before, but wish to add it to my collection. Klengenberg very good, particularly reference to Stefansson. Interesting contrast to Freuchen....Very uneasy hours spent meditating on course to take - so many complexities....Wish to make Mackenzie - afraid that is out because of sailing date. Reindeer Lake? complex. North West River? - but if I was stuck there it would spoil summer. Think of these all the time. Must decide very soon. Unfortunately know too much of these trips for my own comfort - obstacles and own limitations."

In any event, Downes booked his passage on R.M.S. Nascopie, and joined her in Montréal that July, immediately following a second trip to the Québec North Shore. The Nascopie, the Hudson's Bay Company's largest ship, freighted mail and supplies, carried Company officers on their annual tours of inspection, and transported employees from one isolated posting to another. On every voyage she would have aboard HBC men returning from "outside" and would, in the course of the northern summer, take on counterparts of theirs who had been waiting years to go on furlough. Since 1933 , when she was fitted with extra passenger cabins, the old Newcastle-built vessel had also been under contract to carry the Canadian government's Eastern Arctic Patrol: room was always found as well for missionaries and a few common camera-toting passengers. The Patrol, which was inaugurated in 1922, was responsible for "policing, care of the natives, and scientific investigation of the region by the co-operation of the different government departments whose activities touch[ed] on northern affairs" (McKeand, 1938:37). In charge of the patrol, as he had been for some years, was Major D.L. McKeand of the Lands, North West Territories and Yukon Branch of the Department of the Interior, a man for whom Downes was to evince something less than admiration. But Downes himself, to the HBC post managers, their clerks, Mounted Policemen, and others who met him so briefly ashore in the course of the trip, must have seemed simply another of 
the "tourists" who arrived annually with the Nascopie. In part he was just that, and we should not be surprised that his freshness shows; yet he knew far more about the north than did other mere passengers, and his desire to increase that knowledge, and to do so through first-hand experience, was insatiable. It would seem from the journal that Downes made a decidedly favourable impression on several old northern hands with whom he travelled, among them William "Paddy" Gibson, the HBC's Chief Trader for the Western Arctic. We also find him in the close company of two scientists, David A. Nichols of the Bureau of Economic Geology, and Nicholas Polunin, 27 at the time, and known irreverently as "the weedsnatcher" by the young Mounties sailing to their Arctic postings.

Sometimes Downes gets his facts wrong (to give just one example, he credits the mountebank Grey Owl with an Apache mother), and in spots his writing is tangled and unclear, or so sketchy as to be mysterious. Indeed, he admits in these pages that he is well aware of the limitations of a journal, or diary, as a full and true record of experience. Nevertheless, this journal conveys superbly a young man's excitement in going north for the first time, seeing places and a way of life he had only read about, and becoming acquainted with men who, like Cabot, stimulated further his hunger for northern lore and gave him ideas for the demanding trips he would make in the years ahead.

The original journal was written in soft pencil on the soft paper of an 81/2" $\times 7^{\prime \prime}$ account book, and contains many drawings, none of which are susceptible to photographic reproduction. I have deleted some passages of a purely personal nature, some repetitious material, a couple of pages of translations of Ungava Eskimo vocabulary, and details of barometer readings and water temperatures. Otherwise, the only differences between the original and the present version are where $I$ have corrected Downes's spelling or punctuation in the interest of clarity. In a few instances, I have been unable to identify fully individuals who are mentioned only by their last names. Information that I thought it necessary or helpful to include, as well as first names or initials, will be found in brackets.

\section{July 14 Lower St. Lawrence}

Very hot and bright. Rushed about and got bags packed. Left New Carleton and took taxi to wharf: at Shed 6 about 9:30. Nascopie aflutter with flags and quite a crowd aboard and about. Mounted police very striking. Given their last charge; then much camera snapping - handshaking - waving, a little weeping, and at 10:07 she dropped her lines. We steamed down river past two cruisers, Champlain and Saguenay; many vessels, much whistle courtesy. This vessel has most extraordinary and weird siren affair imaginable. Much confusion, and I found myself with Douglas Leechman and [C.H.] Ney, the former an archaeologist getting off at Burwell, the latter Geodetic Survey, off at Hebron. Nascopie (Fig. 1) very well arranged, more room than one would imagine. Actually luxurious to me. Lunch excellent indeed. However, sat opposite an hysterically talkative old bitch. Long

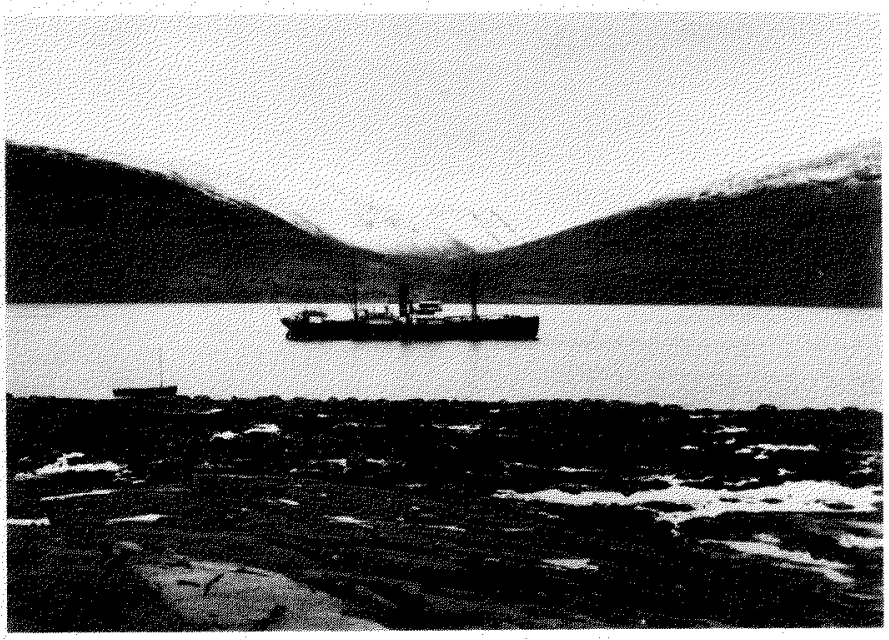

FIG. 1. "Nascopie"

chat with [James] Cantley and Dr. [David A.] Nichols (Geologist - working on marine terraces - must get more stuff here - he is very keen on subject). Ney chatting on divergence of plumbline due to non-homogeneous character of sub-stratum. Met [Constable "Baldy'] Turner, RCMP at Baker Lake, fellow that brought [David] Irwin in - said the only reason he got away with it was because he was so tough. Leechman a bit contemptuous of [Frank G.] Speck and Willoughby. Turner to Lake Harbour for four years. Handsome chap with fine teeth. Said Irwin went back to King William Land and was brought in by Eskimos; lost in Barrens and did not know where to go, different story from that in his book [Alone Across the Top of the World (1935)]. Turner said last of [John] Hornby party was too weak to shoot caribou though they appeared. Says [Hjalmar Hammar] Neilson best man in North today as lone hand. Nichols first to recognise tremendous possibilities of aerial photography for physiographical work, spoke of pleistocene-glacier effect on beaches, ice in fiords, etc.: how all material is wrong. Possibility of marine trough and connection to Arctic through and across Dubawnt-Back-Coronation. Shows up by aerial photograph. Tremendous fund of information here. Almost too much to write, it is piling up so fast. Blue spots on ass of newborn Esquimaux.

\section{July 15 Gulf of St. Lawrence}

Morning spent in wandering, reading, and chatting. Passed old Tadoussac after running quite close to coast then squaring away for Father Point. Saw cormorant, white-winged scoter, and, as usual, the Beluga, followed by five persistent herring gulls. Looks as if it might clear up, though thick to NE. Wish I might get down tales I hear and fragments hot off the griddle, but it is impossible - there is so much, and it comes in such snatches. Crusing along serenely with snatches of sleep and chat in PM. Talked with Turner about Hornby and [James C.] Critchell-Bullock. Neilson is at Great Bear, also D'Arcy Arden - both at Cameron Bay: latter made about $\$ 20000$ on strike but blew it all in town. Talked with Lloyd Roberts, newspaperman who is historian for the trip. He knew Grey 
Owl very well. The latter an Apache mother, Irish father, his books sell prodigiously in England. Then talk with Major [D.L.] McKeand on Franklin search (I knew as much as he did about it), also about Hornby, who he considered eccentric but not crazy. Says he was likeable chap. Talked about his beating him and [Guy H.] Blanchet - a surveyor - in squash. Hornby absolutely undependable as the wind. Turner says he was ordered to arrest Critchell-Bullock, who tried to fly into Thelon to find gold that Hornby claimed was there. Lad with Hornby who kept the diary to the last was named [Edgar] Christian: put it in the stove to save it. Talked of George Douglas, now living at Lakefield, Ontario, who wrote Lands Forlorn. How Critchell-Bullock walked about Ottawa in summer clothes in sub-zero weather, and went to butcher's, buying, then eating, raw meat, much to mingled emotions of admiring young ladies. Should make attempt to pick up Lands Forlorn. Also tale of one Herbert Hall, huge trader at Ungava, Diana Bay and Sugluk; has walked [with a dog team] to Toronto from there twice! Second time to get concession of more freight - gets fifteen tons from government for tending government direction station. Then saw some movies of Chimo, and particularly Fort McKenzie, 200 miles up the Koksoak. Fine pictures of packing and poling. Seems to be quite a little growth there. Pictures of Manitou gorge, a bitch with a five-mile portage. Indians all Naskapi. These taken by factor there: Charlie Stephen. Long talk with a young fellow on Clyde Harbour Eskimo - here are some facts: politeness of Husky tongue (as [Peter] Freuchen) - not bring me chair, but I wish I might have chair, etc. He is in great game country. Eskimo sighting bear through scope can tell age, length of time since feeding, sex at tremendous distance. Bears always make for snowbanks - track them, see tracks great distances and then cut around - anticipating them. Old ruins upper Frobisher Bay on Tulik River. Also jade in situ at Home Bay. Jade wick trimmers. Tattooing disappearing. One fine example at Pangnirtuk - use thread dipped in soot. Not much in way of bear pants because they are not as warm as deer. Care of Husky in hunting caribou and leaving them in valleys when crust on snow. Must get this lad's name.

\section{July 16 Lower Gulf of St. Lawrence}

Just sight west end of Anticosti at breakfast time - also North Shore, Mingan: very irregular sugar-loafs just visible, seeming to rise from the very sea. Closing in with fog and rain. Mail is taken from Fort McKenzie to Seven Islands every winter by Indian with wife and child: 700 miles; two months. Forgot to say we had fire drill yesterday PM, and I wandered around to my station, the last one; everyone looking ridiculous and embarrassed, throttled with life belts. Sighted a blackbacked gull at noon. Some comments should be made at this time anent the bath situation. Whereas I have seen only one name officially listed, baths are being taken all the time and are heralded by the strangest hissing screeches of escaping steam and a snorting undertone roar, quite alarming when first heard. Yesterday I put on my new underwear, finding it quite satisfactory. Had some terrific rum of Leechman's today, 35 over proof. Really some of the most potent brew I have gagged on in a lifetime. $L$. has great and slightly weary eye for the ladies. Besides the horsy Miss Strang, we have a couple of younger fillies from near Winnipeg and these are squired often by such males as run afoul of them. The rum is commission Demerera, $\$ 2.15$ a quart. That even in the loftiest scientific circles one cannot believe what one may see is apparent in the case of my cabin mate, Mr. Ney, who has a large, handled grey box with the inscription ASTRONOMICAL INSTRUMENTS: WITH CARE on the side. To date, this has turned out to be but a " $B$ " battery which he uses to operate his electrical razor. After supper an extraordinary session with [William] Gibson, who was at the Coppermine and on King William Island, and who knows more than any man alive of the true set up of the Franklin data - also knows D'Arcy Arden, and had real story of Irwin. According to his logical conclusions, [Major L.T.] Burwash's account and thesis of one of the ships having sunk east of King's is absolute bunk based on cache which could not possibly have been Franklin's and must have been Amundsen's. Gibson on his trip to west side between Gjoa Haven and almost Victory Point found 10 skeletons and cloth. Description of finding skeleton island and making cairn, later Eskimo bringing in bones to trade across the counter, is wonderful. Natives still bringing in parts of [John] Ross's engine. In last few years have brought in link of cathead chains identical to one that Rasmussen got, also sounding rod and deck fitting. Thinks Rasmussen (a lad who loved his gin) greatest of northern travellers. Met him at Coronation Gulf. Rasmussen would eat raw, rotten fish with the dogs and finally died by complications brought on probably by this. [There follows a list of "proofs against Burwash."'] Bunk in Irwin story. He was tough, all right, slipped through, but his reports terrifically exaggerated - a little cracked, and a terrible violinist. Fed and cared for by traders and such innumerable times; got to King William, and [L.A.] Learmonth, who had been caught short, helped him out, outfitted him and sent him down with Back River Huskies to Chesterfield and Baker Lake. All the polygamy and the King Cotton stuff bunk - inoffensive little old man with one wife and three children. Article in this last Canadian Geographical Journal ["The Copper Eskimos of Coronation Gulf,' by C. H. Dowell, Vol. XIII, No. 2 (June 1936):61-82] on Copper Eskimos absolutely false. Gibson knows man on cover - who is a King's man dress only party or photograph dress - polygamy nil, only one case Sherman Inlet of polyandry and that one man with wooden leg and the other the hunter \& dubious sexual affinity. Other picture also false. Impression of lack of modernity is ridiculous. Fellow shooting bow brought in for murder way east from Copper Eskimo group. Place full of traders and missionary influence strong. Ogulluk - of Irwin - bunk. Saw movies of Governor's trip on Nascopie 1934. Some good pictures and very amusing. Marvelous tale of the Eldorado strike. Gilbert LaBine and a dentist named Bannerman from Edmonton, a big game hunter, were flying over Great Bear Lake and Bannerman spotted the wide vein of quartz. [In fact, LaBine's companion was E.C. St. Paul.] They went down, and he wandered off with his gun. LaBine investigated the vein and 
found some pitch-blende samples; though he did not know just what they were, he realised he did have something. So he flew out again, had it analysed, and, upon discovery of what it was, rushed back by plane to stake his full claim, which he had not done before. There he found a party of the Dominion Explorers camped right on top of the vein. He was in a hell of a fix and heart in his mouth that they would look down and see what they were on. Also, everyone watches the other fellow like a hawk in this game, so he dared not move. Eventually they did leave, and he got in his claim. From Gibson.

\section{July 17 Belle Isle Straits}

Played chess all AM, beat Ney and the historian, latter in very tough game - over hour long. Cantley told me that [Philip H.] Godsell was a victim of booze pretty much and that his wife wrote most of his stuff. [Godsell's Arctic Trader: an Account of Twenty Years With the Hudson's Bay Company had been published in 1934.] Shoots his mouth off a little too much, he thinks. Beginning to clear. Sighted both Newfoundland and North Shore about 3:30 PM, beginning to make for Straits. Reading Gibson's manuscript on Franklin with his own researches. Find it very fine. Gibson \& [William M.] Skinner: Gibson headed party in 1931. Started Gjoa Haven Petersen Bay late in June. First, Todd Islands; here, Eskimos told [Charles F.] Hall in 1867, there were five bodies. Hall found one and buried it. Gibson found remains of four others. One in sandspit - blue cloth still with it. Old cairns torn down, not able to locate. Pfeffer River next - one remains. Douglas Bay next - seven skulls and accompanying bones there. Tulloch Point, a disinterred skeleton and broken-down cache. At Cape Herschel on Simpson Strait Captain [Francis R.M.] Crozier and the survivors had united the waters of Pacific and Atlantic - 1848. Sixty-five have been accounted for out of the 105. Records with 35 or $\mathbf{4 0}$ in Starvation Cove destroyed by children \& box kept: [Frederick] Schwatka Franklin, 23 others must have been buried at sea. Played shuffleboard with historian and gave him quite a trouncing. Supper and long talk with Gibson on priest murders [Coppermine Rijer, 1913]. Story was that they [Rouvière and LeRoux], frantic to get back, tried to use dog whip on Huskies hauling sled, and one was knifed while urinating. [H.V.] Radford \& [T.G.] Street: Radford, crossing from Chesterfield to Coronation [in 1912], threatened Husky so he might get to Bernard [Harbour] HBCP, by holding him over ice crevasse. Doak \& HBC man murder: fight near Kent Peninsula, old Pugnana a shaman - six or seven Huskies killed, probably women at bottom of it, and youngster of 17-18 shot Pugnana in back. Brought in by Doak with witnesses, and then liked by him, so the other witnesses were sent off to sealing grounds with Wilentz. This young chap [Aligoomiak] thought some evil intended and shot Doak through abdomen while asleep, then shot HBC man through window pane - straight through heart. Huskies came in to trade - disarmed him, took him to Wilentz. Fine act, and no credit. If they had not done this, the other Mounties probably would have been slaughtered, with Wilentz and two that went to Bear Lake for mail. Hanged as example, but to Eskimos it simply meant two whites killed, two Eskimos. [RCMP Corporal William Doak and HBC trader Otto Binder were murdered at Tree River on 2 April 1922.]

\section{July 18 Working N. up Labrador Coast}

Bright and sunny on arising. Went out, and on port side saw beautiful berg very white in sun off Labrador coast. Also small bergs on starboard side which are a beautiful greenish blue. Sooty shearwater at noon and two greater shearwaters. Saw what I believe to be the white-bellied booby - is this possible? Many bergs passing, mostly inshore - probably grounded. Marvelous translucent green-blue. Fog closed in late in afternoon. Fulmars, shearwaters - one Brünnich's murre - all day. Beaten two games of chess by historian. Mr. Smith and others say no salmon on Baffin Land. Salmon as far as Koksoak and no further. One 50-60 pounds netted at Chimo. Arctic char of $50 \mathrm{lbs}$. netted.

\section{July 19 Off the Labrador}

Ney seasick as well as several others. Felt better after a little rum. Mooched along all day in heavy fog. Minister ill, so happily no service. Heard the rotund Major dogmatise on Migratory Bird Act. Also on the Putnam Baffin expedition in which they applied for specimen collection and ate the ducks and published fact. Find Major a dogmatic, puffed-up old fool, but fine master of ceremonies for the elderly ladies. His ideas on the Migratory Bird Act are fallacious and frightfully biased, if our Biological Survey Reports and my own observations and knowledge are at all correct. Also, he gives impression the natives and Canadians are strict observers of the law, while we are not. A lot of bunk, for as the HBC men tell me, if the natives observed the game laws, they would starve. In PM saw flock of murres and some guillemots. Very heavy fog with wind a bit east of north. Talked with HBC boys, a group of remarkably young lads, one from New Zealand [E.B. Maurice], going back again. They are good observers of bird life and such. Charlie Stephen, who was at McKenzie four years ago, tells me both the Cree and Naskapi paint skins there, particularly the marten - and always first caribou. Old days, first skin an Eskimo boy took was given to women, who tore it to bits. Also Indian always gives game he shoots to others. [S.C.] Knapp story about Eskimo with birds on head meaning good hunting. One of the lads who was at Chimo and Leaf River says no harlequin ducks in those areas. Long talk after supper with Gibson, Cantley, and [Sid] Thomas. I asked Gibson about the problem of evacuating bowels at $\mathbf{4 0}$ below, and he says they build a little snow-block windbreak and use paper; Eskimos use snow. Hands, not ass, are big problem. Story of having to tie up Major Burwash's pants. Ney having to run from Providence to Hay River across Slave. Got talking about planes and went on and on. Some great yarns; I wish I might get them all down. However, some highlights. The Italian Armada at Cartwright - MacAlpine lost party, 50 grand for diary - a put-up job. Flying from Chesterfield to Wager Inlet reading detective story, ending up Sherman Inlet. Engine 
dropping off. The wild plane at Norman. Bringing plane out with two pistons removed. Thomas story of "Scotchman" at Suez. Earthquakes and disappearing islands. Considerable excitement with receipt of Marconigram saying a $\$ 30$ grand fur robbery by plane with six men on Mackenzie - static so bad did not get the post - probably Smith or Fitzgerald. May later. [The robbery took place at the HBC's Fort Nelson River post.]

\section{July 20 Off the Labrador}

Have had some very weird dreams - some erotic, others exotic - except last night, which is why I mention it. Had fight with bear one night. Amazing the persistence of prospectors. Stephen told me of four prospectors, including one Shepard, who came in by Great Whale across to Koksoak, and Shepard ran the Manitou Gorge - poled up to McKenzie himself. Lynx did not appear on Baffin at all until five years ago then appeared in numbers. Huskies had no idea - thought they were devil. Now one or two each year. Talking with Ney, he told of interesting divergence of plumbline from perpendicular brought about by attraction of large land masses or repelled by lack of mass; greatest divergence is on Gaspe near Shickshocks, with possible ocean depth to repel plumbline. Spent morning getting information from D.A. Wilderspin, lad who was at Chimo in ' 33 and Leaf River; going probably to Dorset, fine point for bird observation, promised to send him a Taverner. Had some interesting observations on birds at Chimo which I have taken down. Ney, Leechman, and I spent morning taking down Husky vocabulary from Wilderspin, which is the Ungava dialect. Have been pushing along very cautiously - sometimes stopping, sometimes a little more briskly with man in crow's nest as we raised an island, and should be in Hebron before long. [Captain T.F.] Smellie has not taken an HBC boat in here for many years. Nice sun and blue sky about 2 PM, but surface fog everywhere, occasionally lifting. Quite a novelty, the sun. Land seen momentarily seemed an island with patches of snow. Late this afternoon was asleep and roused by Leechman. Went on deck: most extraordinary sight of grim ageless grandeur - the rugged (an insufficient word), great bold coast below Hebron: the "Bishop's Mitre" 3000', splotched, gullied, and much snow. The sun shining on two huge bergs and not a speck of green. Wrinkled and twisted as we drew in nearer; the glasses revealed great dikes of dark - diabase or trap - huge twisted bands of gneiss, and on one great rounded island a very odd succession of quartzite in old bedding planes, blocks superimposed on blocks - then great bands of dark dikes with infusions of light lemon-coloured streaks. Could never describe these snow-topped, wrinkled, towering masses rising from the very sea. One huge turreted berg had an amphitheatre hollow centre of pure dark green, and high up on side facing western sun a splotch of most brilliant cobalt blue. On we went, gradually drawing in to this coast. At last the opening to Hebron. On the towering heights perched cairns - black and solitary against the sky but very noticeable because of the bald rounded summits. We watched the promontory disappear, and the most

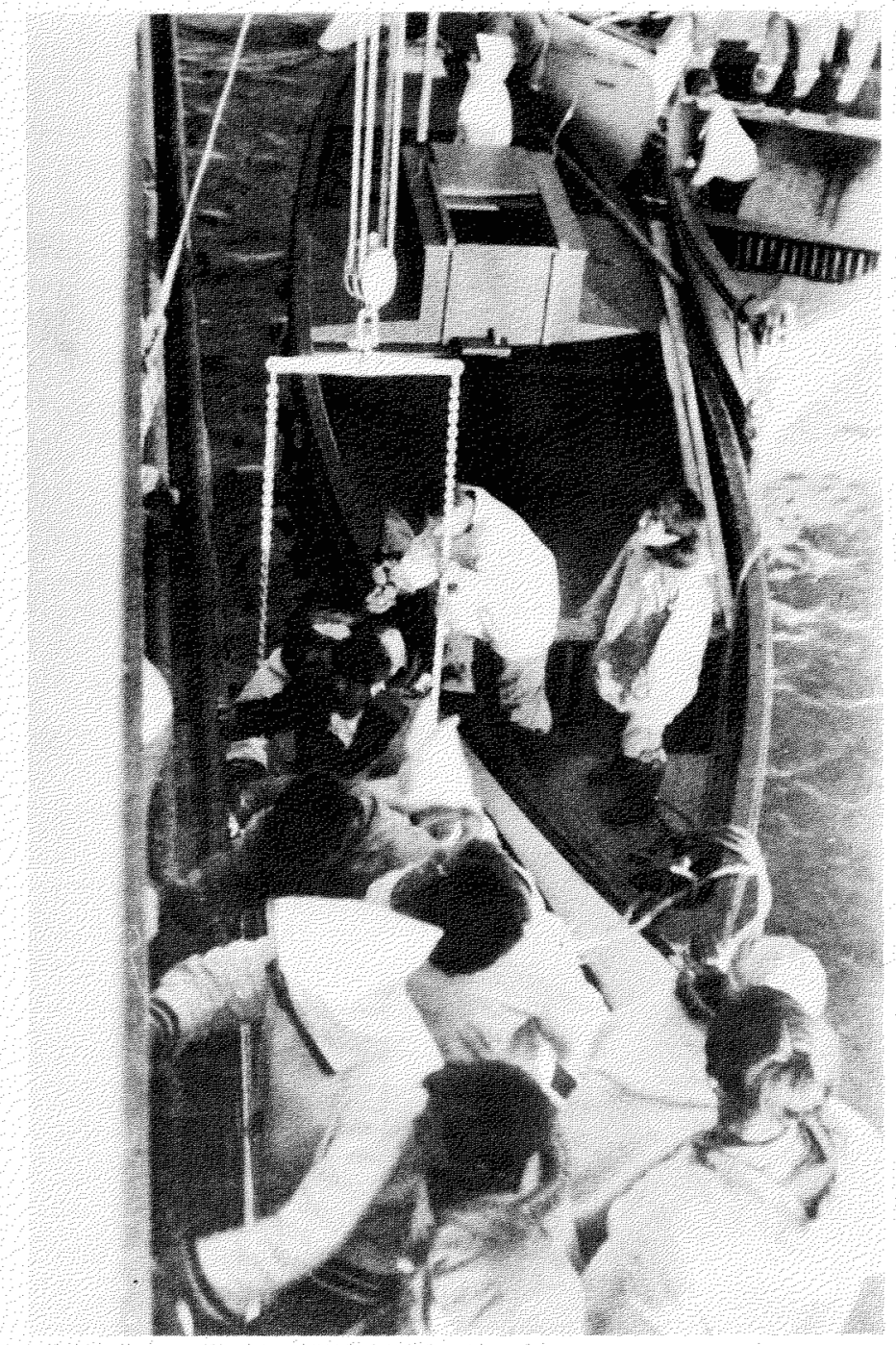

FIG. 2. "Huskies coming aboard, Hebron"

curious mirage that I have ever seen took place, for the two peaks changed into weird shapes while you watched: now a point - now a jagged fir tree effect - once like a huge bird on one leg - then planed off into a flat top. Coming into the bay at Hebron I saw two gigantic glaucous gulls - enormous creatures. A power boat loaded with Huskies appeared and at last came within hailing (Fig. 2). Not a sound in this great, vast stillness as we crept along with a man on the starboard side heaving the lead, and then they broke out with a highpitched wailing yell of greeting, waving furiously to us. Coming round the point, we saw the red-roofed cluster of houses on a pale green background, huddled beneath a huge peak with an ocherous red gash: Hebron. Two more boats put out, and swarms of Huskies, Mr. Harp the Moravian Missionary, the Ranger, etc. appeared. A little power boat with a blue flag bravely flapping, with the words "Moravian Mission" printed in white. Mr. Harp, an Englishman, is a tiny little fellow, nattily dressed in a checkered tweed coat. One old Husky had a full-dress tailcoat with the tails cut off. I was surprised at dark pigmentation of some and also the red cheeks of others, all grinning and merry-appearing; wearing mostly duffel parkas 
or dickies. Ney went ashore for observation. Fort Garry was alongside and is now taking on cargo. A three-master, typical Bluenose banks fishing schooner. Clearing, but a bit overcast at evening; dusk almost over at 10:00. Amazing great wiggling dike of black against the dirty white of most of rock. Just been reminded of Sparks at Clarke City, great authority on vacuum tube, describing atoms - male and female, green and red ones crawling around.

\section{July 21 Hebron, Labrador}

A great and busy day. Bright and fair. Put off after breakfast with Mr. Nichols for Geological tour. Started at dyke that runs up hill on N. side. This black dioretic dyke very obvious entering the harbour. Taken ashore by Rev. Harp \& Huskies. Started off finding remarkable cutting of granitic gneiss. Dyke about $12^{\prime}$ wide runs across strike NNW-SSE. Typical Labrador. Followed this up over hill. I spotted piece of actinilite float. Nichols took some sand at $160^{\prime}$. Find way to get elevation is to halve my bar. reading. Worked along, and I located slabs of steatite and traced this float down big fissure to the steatite in situ - very odd, hid nodular inclusions in gneiss - steatite core surrounded by thin ring of mica or actinilite. Took some pictures. Worked on around and found a little bay filled with grounded ice which would growl, and break with thunderous cannon shots. Terrific mosquitos - never seen anything like it. They would cluster to your leeward side and when you stood still you could hear a faint roar of them. No obvious raised beaches. Found one old encampment site. Crossed over one raised boulder beach. Many erratics at 230' dropped by sea ice. Clambered around point toward town, very precarious going and legs a bit weary. Very mongrelly dogs, as good dogs are off with fishermen. Saw Ney's outfit. Eskimo tent, and I went in back of it to photograph a kayak: then heard the strangest and most upsetting sound - a whimpering crying impossible to describe, thin as a knife, and without ceasing. (Coming on ship later, I learned a boy had just died then.) Women rolling flour barrels. Inspected post. At last to boat. Fine supper. Eskimos came and played; their brass band mostly hums. Very good; occasional lapses to empty spit. One fellow with tuba intently followed his one sheet of music for each song. Quite good harmony. Then a feast for them, never seen anything like it in my life. Bread, all the stale bread we had, and bully beef; a big can of lard, they just dug in, both hands, and gorged, stowing it away in pockets, handkerchiefs, and hoods of dickeys. Most amazing gastronomics one could imagine. Then they sang - women in their high soprano. Movies by Mr. Harp of Mission - eating eyes out of fresh caught écalug high point. Talking about Eskimos suckling children to advanced age, Leechman swears he saw a youngster sucking at a breast pause and smoke a cigarette. All the members of the band had their Sunday go-tomeeting clothes on. One great regret, did not sign guest book along with names of Lindbergh (Mr. \& Mrs.), MacMillan, Bartlett, and such. [Nicholas] Polunin finally came back with his neck a mass of bites from "little creatures." He saw strange hawk of buteo variety, white throated sparrow, and pipits. Norwegian mosshawk? May I note at this time that the notes taken here are all just notes in their baldest form. Travelling in this manner with material pouring in on one, there is no chance for lyrical digressions and one is fortunate to get down a quarter of what one sees and hears. I expect to expand this material when I get back - the gods willing - and live in the hope that I may remember some of the material that I have jotted down here. That is the trouble; so much slips by - and when chatting, you cannot sit with a notebook in hand and take the material down. I am constantly haunted by fragments of stories which appear and disappear during the day. As for instance, take Ney's marvelous story. We were talking about difficulties of Eskimo language and the impossibility of learning the Slavey (Athapaskan) tongue. A young fellow was down the Mackenzie and all set to learn the Athapaskan lined up an interpreter, and appeared bright and early with pencil and notebook. "O.K." says the interpreter, "write this" - (spitting sound) - "that's the first word." The Athapaskan is tonal - high \& low words. Should write to Roberts for photo of Eskimo band concert. So many incidents simply defy description. The crying in the Eskimo tent; the first sight of a berg; first sight of headlands; glaucous gulls over the hills; Eskimos singing "God Save the King"; the vocals of women - the high, then pure soprano, vibrant like a wire; the mirages and mists. Very remarkable great mare's tail in sky - have some wonderful cirrus cloud effects here. Ney back on board. Should write a paper on the falsification of the North by even the more reputable. Story of HBC boy from New Zealand [Maurice] who went into big London theatre to see pictures, and saw lovely coloured pictures of Frobisher Bay and a monologue on the native - untouched by white man - devoid of contact with civilisation and still primitive never saw a white man - and first thing he sees is his own personal servant climbing aboard: these [Donald B.] MacMillan pictures. Gibson believes Barren Ground brown bear still in existence. Huskies have great fondness for blue yachting cap; occasionally wind handkerchief or fur about it; not particular about putting it on straight. Usual costume, dickey of white Grenfell cloth over blanket dickey.

\section{July 22 Off the Labrador}

Pulled out of Hebron at 4:00 AM and ran north all day in heavy fog, seeing no ice, this an extraordinary and unprecedented thing. Last year they were held up eight days. Gibson tells me the man who got most white fox last year in Western Arctic was Alexander Stefansson. Mother was with Stefansson to do sewing - result the above. Trouble resulted in man with Stefansson who had married [Charlie] Klengenberg's daughter - signing paper to effect he was father got him out of it. Woman never married, feeling he would come back again. Trapped on Banks Land, worthless half-breed. Long talk with Polunin. Ellesmere flora known better than many local areas. Never seen lightning in Clyde's: Knapp. Spoke to Charlie Stephen about nimában \& melenshán. Leechman gave me Dorset stuff: chief characteristic, no drilling, no bow drill all is slotted. Saw a huge berg at night. No definite darkness; 
seemed even at 12 midnight that dawn about to break, even with heavy fog.

\section{July 23 Off the Buttons, N.W.T. then Port Burwell, N.W.T.}

Fog until 11 AM, then cleared. Took pictures of fine huge berg with swarms of kittiwakes perched on end. Also saw Bonaparte gulls, long tailed jaeger, murres, fulmars. See land. We have rounded Chidley and are working SE. Feel very turned about now, going south after north so long. Played chess with Roberts and was licked. Very clear above, but very cold, particularly on hands holding glasses. Birds this PM: definitely a Brünnich's murre, also horned lark. Golden Eagle (probably [there will be] doubt, but what else could it have been?). Definitely black guillemot. Later: OK on Golden Eagle, as [J. Dewey] Soper records it as not unusual. Nichols and I did our stint on sand, etc. Quite a lot of float limestone, though we found no fossils. Took several pictures; must send to National Museum for some of Leechman's photographs of Eskimo ruins. Nice bright day with very strong NW wind. [There follows a "Brief note on geology of Burwell as glimpsed."'] Forgot to mention two days ago extraordinary early morning fog phenomenon: heavy morning fog with a perfect arc to west - pure white - like a rainbow in form and smoky white in colouration. Padre appeared, and the seasick spiritual Reverend [Ronald] Wenham staggered aboard the trim little Koksoak to shake hands with his parishioners. Eskimos very hirsute on upper lip, scraggly on chin, none on jowls. Leechman and Ney will be leaving us soon, as Leechman works around here and Ney joins the Fort Garry to do Ungava Bay.

\section{July 24 Port Burwell, N.W.T.}

Overcast, wind strong $\mathbf{S} \times \mathbf{E}$. Waited around for transportation to shore; usual delay. This is an exasperating and unnecessary feature, what with plenty of boats around. Particularly unnecessary to Gov't officials who have a limited time. Waiting and waiting. At last got off with weather very threatening. Polunin set off by himself. Went with David Nichols, took sand specimens up to 263'. Followed by handsome black husky dog, all the way. Wandered about and glimpsed Polunin. Extraordinary and quite excellent fellow: found but one new flora specimen. Took example of float limestone - very compact and buff-coloured, no fossils in it. Never have seen more confusing and difficult country. Saw: several pipits as well as raven - dismal croaking affair horned larks, snow buntings. And a very curious bird. Head like a ptarmigan, white head, neck - underbody snow white - black back \& tail, except outer feathers: rock/willow ptarmigan (Ungava)? Very precipitous cliffs and much talus; all rocks extremely angular; no rounded cobbles or boulders, no terraces or cobble beaches. Squatted under huge boulder in driving rain and ate our lunch, sharing it with husky. Finally came back after snowslide down slopes. Great quantities of snow in gullies, country full of pot holes, little ponds, and precipitous cliffs. Loafed around on board rest of time.
Strange red "sea rat" jugged up, taking it back. Very odd. Listened to Major shout his line. Got quite a slant on things a la Leechman today, very revelatory. 350 green buffalo hides from Wainwright Park shipped up here to Huskies last year to supplant extinet musk ox.

\section{July 25 Port Burwell, N.W.T.}

Very foggy and cold. Wing strong from SE. Went ashore in morning to look for limestone slab. Wandered about all morning but could not find it. Got one piece of fossiliferous limestone. Followed constantly by big yellow husky dog, very friendly. These dogs follow anyone in the anticipation of a meal of faeces. So it is most amusing to hear the ladies exclaim how friendly the nice dogs are! Came back to post and sat around and waited for [W.E.] Lyall to show up. Chatted with Knapp and men from Payne River, Leaf, and McKenzie (Fig. 3). Had some tea and Scotch. Found .450 Mannlicher from Oxford Expedition. Bought seal dickey from Ernest Lyall, post manager at Burwell, for $\$ 10$. Must get it trimmed. He had a deerskin one, but it was in rather poor shape, and considering his demand of $\$ 12,1$ decided not to get it. May regret it. Finally came aboard. Saw beautiful stone pipe from McKenzie

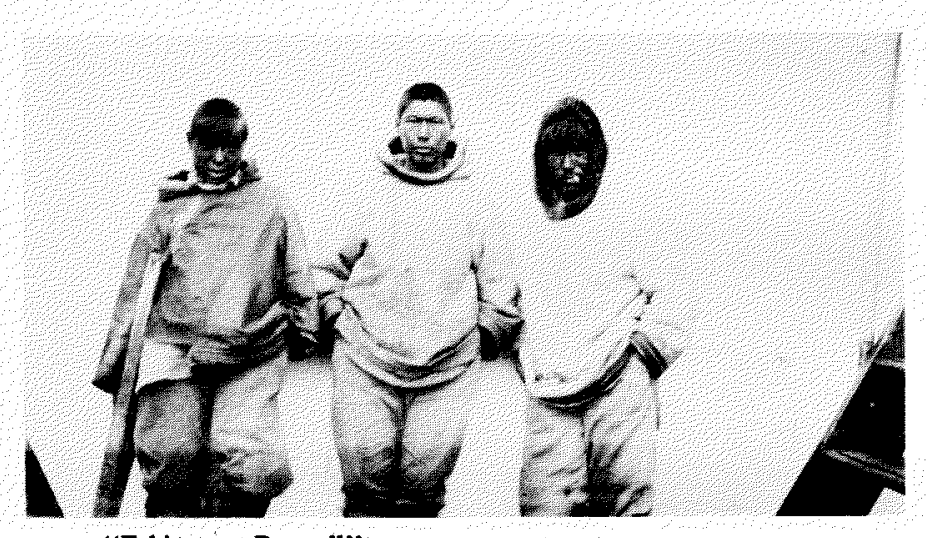
FIG. 3. "Eskimos at Burwell"

and some nice moccasin bead work. Mr. Smith \& wife Audrey \& dog, Charlie Stephen and others, Rev. Wenham (looking a bit wistful), and Huskies cleared at 8:50 PM for shore, and will go on down to their various stations in the Koksoak. Rather sad. One spontaneous cheer, and off they went, waving as far as we could see. Tell me Payne River through to Harrison not a bad trip, two weeks. Might make Sept lles in little over month; Sylvestre [McKenzie] takes 59 days. [McKenzie carried the HBC winter packet the 700 miles from Fort Chimo to Seven Islands.] Nichols brought me some interesting specimens from around Mission - gametiferous stone with large hornblende inclusions, some disintegrating to micaceous form. At last pulled up the hook - Nichols rushing forward and seizing specimen of mud off anchor chain and flukes. And headed out channel into Straits. Blowing very hard. In evening long chat with Gibson. Says Godsell very much detested and known as a soft traveller; makes cariole be brought right up to door, then boughs placed so feet will not get touched with snow in the bush. Says there are some fine Tunit ruins on King 
William which Rasmussen missed: 20 miles S. from post, 100 feet up on high raised terrace. King Wm. all raised terraces. Shale and limestone shingle. Great ice pressure from west forces beaches up in fantastic shapes - tunnelling right into it. Must not forget the old trader on Baillie Island, wonderful story. Had jig-saw puzzle contest, and [Thomas] Deachman Gov't party secretary - and I won contest: 50 cigarettes each. Very welcome, as we are almost out. Should hear the traders' opinion of the Major's buffalo hides - salted stiff \& useless, cannot give them away.

\section{July 26 Hudson Straits \& Lake Harbour, Baffin Island, N.W.T.}

Woke and went above to glorious spectacle. Moving through Hudson Straits; sea calm as a millpond and everywhere floating bergs of smallish size. These quite separated every conceivable shape - many different colours. Blue sky, long trailing cirrus clouds, very mild. Went up in eyes of vessel. Innumerable roving bands of razor-billed auks and some dovekies. Very funny to watch them flap along water getting out of way of vessel. Beat their wings furiously on surface without getting up enough speed to take off, and finally end up by taking a disgruntled upside-down dive. Almost ran over one, and I could see him swim under water for quite a way from directly above him. They use their wings in swimming just as if flying. Church was held by [Rev. George] Gillespie, parson from Chimo - annoying God's mouthpiece, and I did not attend. Wrote diary instead and watched shore of Baffin Land draw near with its fringe of shore ice and scattered small bergs. Again saw that extraordinary phenomenon of constantly shifting mirage of a promontory, shifting from a rounded point to innumerable contorted shapes. Raised Big Island about 10:30 and passed alongside going on up the inlet to Lake Harbour. Geol. note here for anyone who may come this way: on the east side of Big Island as one approaches, there is an excellent example of thrust faulting. The strata of the gneiss is very obvious, and so the fault is particularly apparent. Picked up pilot and moved on up inlet. Went on deck and wonderful spectacle of woman in true pattern (but for dress) who had come aboard with her child in the dickey hood. The youngster, every once in a while, would take one of the braids to suck on. The woman and child both appeared to be very clean, and the tail dickey was handsome (seal). The approach to Lake Harbour is a lovely one. A fairly direct inlet past innumerable islands and points. Appeared much greener than Burwell and with more geological variety. The wrinkled gneisses are brown from slight ferrous oxides and look like the oldest rocks in all the world. No clean slabs or faces - everywhere the broken, lumped effects of centuries of frost and extreme temperatures - fractured and crumbled. By the time we got to the narrows many had come out to glimpse their new home, particularly police, as some are slated to stay here, such as Turner, before mentioned. The police barracks in attractive blue and white were the first to appear, then the HBC in white stones high on the shelving cliff and the red roofs of the Company. Of all the parts of the North (so far), this appeared the spick \& spannest and really quite lovely. Some interesting colour contrasts in the intrusion of great surfaces of crystalline limestone thrusting its pure whiteness into the more sombre purplish brown gneisses and the startling orange-yellow of the exposed crumbling hillsides. The vivid white of the post buildings in this clear air is dazzling and the water at base of the limestone is a brilliant glacial green. The various buildings are set off by white-washed stones and everything presents a handsome, tidy appearance. The little Nanook, HBC vessel, was hauled out and also looks very trim. As we came up the in-

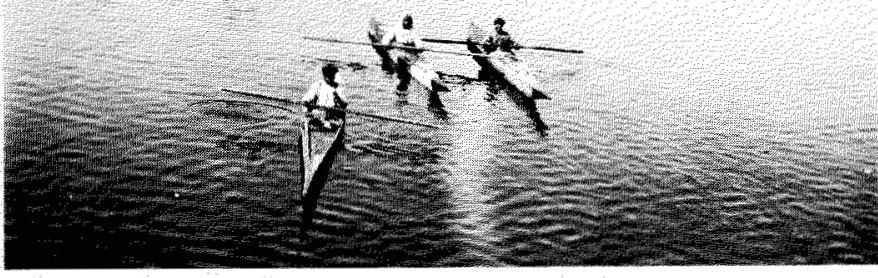

FIG. "Kayaks, Lake Harbour'

let the Huskies appeared from a cove in kayaks (Fig. 4), canoes, and whaleboats, the latter with leg o'mutton sails and jibs. As they followed us up, it almost looked like a Plymouth Yacht Club fleet running for the finish line, although all manner of oars were employed. The vessel let loose the wellknown wintigo scream, which was thrown back at us magnified. Finally let the hook go with a tremendous roar and shower of rust - "Two chains," ding-dong on the bell "Three chains!" dong-dong-dong, etc. Had lunch and shortly thereupon mosquitos began to arrive in great flocks, permeating dining saloon and everything. All prepared to go ashore with every mosquito-proof known being worn. I adopted the usual Lawrence-in-Arabia; one of the girls used the Captain's donation - viz. an inverted canary cage in appearance; and Polunin broke out with a flying helmet, cigar, and pair of inverted blue \& white drawers - very fetching

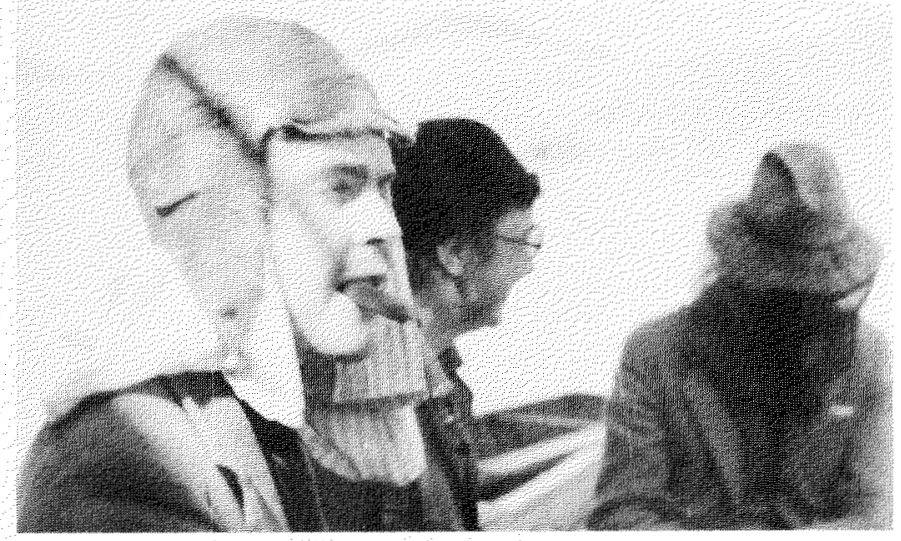

FIG. 5. "Polunin broke out with a flying helmet, cigar, and pair of inverted blue \& white drawers - very fetching." ( 26 July)

(Fig. 5). We set out and landed. The water is marvelously clear here. Nichols and I set out for high promontories, ex- 
amining rock. The gneiss in spots is almost quartzite at contact and feldspar in other zones. Some places the feldspar inclusions are enormous glittering blocks, which shine like mica. Much float mica about, and a large deposit at some distance was formerly worked by whalers, as were the graphite and garnet deposits. Very interesting, the thrusting of the softer limestone up over the harder primitives so that the limestone appears in five distinct huge thrusts. Climbed to an inutshuk [sic] at $460^{\prime}$ back of post which gives a fine view of the country. Never have I seen mosquitos as large and as extraordinarily abundant as these - literally clouds. These bite, but do not seem to poison much and also do not hum so loudly as ours and are very easy to kill, whatever good that futile practice may

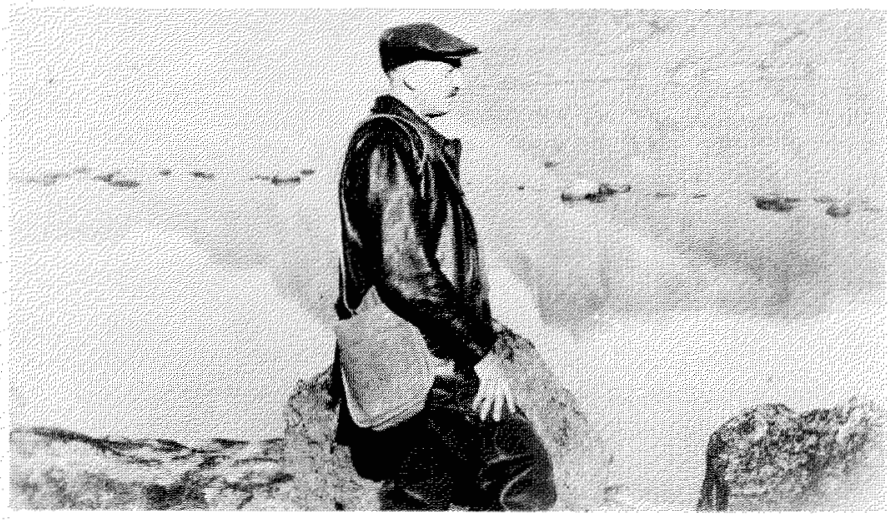

FIG. 6. "David A. Nichols, 'senior rock-snatcher",

be. Took a picture of Nichols - hope it comes out (Fig. 6). Even at $460^{\prime}$ height was one of the common rock depressions and tiny lakes so common here, and it was alive with what seemed to be a caddis fly pupae in the usual case: these cases so studded with tiny mica particles that they looked like glistening animated little tubes. Very little clay, and everything a sugary-coarse gravel from disintegrating gneiss. Some of the gneiss was garnetiferous - took specimens. Wandered about down below. Leechman picked up a beautiful calcite specimen showing fine twinning. Oddity about Husky tents (Fig. 7) is the use of a wooden frame and small wooden door - not in evidence before. Husky women do not carry

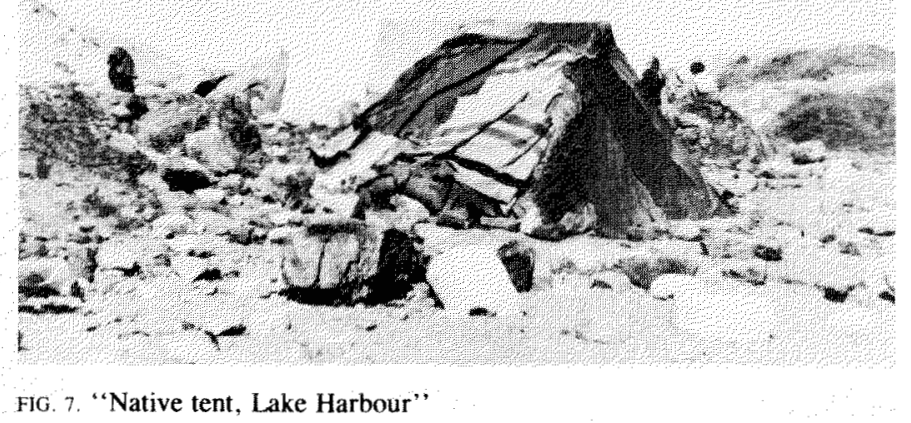

babies in their hoods but in a large pouch at the back of the dickey. Hot and tiring climbing about. Temp. $72^{\circ} \mathrm{F}$ on top of hill. Rather odd, $72^{\circ}$ being thought of and felt as very, very hot. See that the Red Sox beat Tigers 18-3 by news bulletin; a long way from Fenway Park. From the top of the hill the strata of the gneiss showed some fine examples of torsion and dip. This country the amateur geologist's or physiographist's paradise, with so much rock exposure. To see old lady Nature's pranks at their most vicious and spectacular - go north, young man. Really an extraordinary year for lack of ice. Sat on natural wharf while a couple of Huskies attracted most of the mosquitos away from me - how they do swarm around them. There is a $28^{\prime}-30^{\prime}$ tide here. Nichols came along and we visited Neilson, the parson, and I bought a doll and an ivory paper cutter, the doll because it showed the hair \& winter dress so well. I gave him $\$ 3.00$ though he charged $\$ 2.50$. That grabbing light of God, Gillespie, was about nailing everything any good gratis in a very rude and annoying manner. Finally we got back to the vessel, still pursued by mosquitos, which again invaded dining saloon. Chief Thomas had his ankles sprayed with Flit - the always impeccable Chief Engineer Thomas. Very light, could probably read all night. Wind light north. High cirrus clouds, diaphanous.

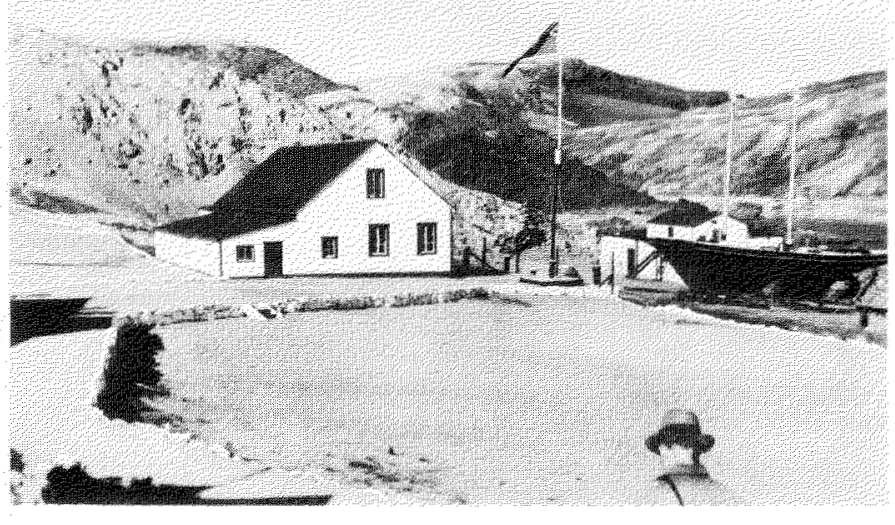

FIG. 8. "Lake Harbour: the Nanook in stocks"

July 27 Lake Harbour, Baffin Island, N.W.T.

A momentous day. Broke clear and warm with fine NNE breeze. Set off with Polunin after breakfast. Were landed at RCMP post, and we set off to go along west shore of long dotted lake on Soper's map of Soper River to eventually reach that river. Best route runs almost due north from this point $-50^{\circ}$ east of magnetic north. Trudged along over first high ridge and on until finally reached lake. As we had wandered considerably westward, we had some argument as to whether this was the lake or not. It is quite different from its mapped conjecture. Finally realised it was, by its bearing. Went down over the endless ridges of gneiss and long slopes of limestone gravel and got to shore. Worked along a way until about an opposite bend, where I found a quantity of post-pleistocene shells which I saved for Nichols - at approx. $160^{\prime}$. Moved along gradually, with Polunin collecting and locating one unreported 
specimen. On until eventually reaching almost end of lake. Had lunch with a solitary upright rock as backrest. Heard a loon but could not see it. Moved on over next limestone ridge, looking down on lovely crescent-shaped lake. Outcropping of limestone with inclosures of garnet and mica, the latter in nice crystals. Some fine views from this elevation. Also phenomenon of protruding limestone that has become oddly weathered, like buns or knobs from the otherwise smooth surface. Below this height was a valley, limestone, with odd sink holes in stone; here found a semipalmated plover peeping. Soon found two babies running about on ridiculously long legs. Moved on over next ridge of old weathered gneiss, and on to a view of Soper River. Here river takes a decided bend and expansion, then rushes down a "chute." A large hussocky meadow, very verdant, bounded on west by steep cliff-like ridge running $\mathrm{N} \times \mathrm{E}$ and on east by a loose, low gneissic tongue. Stream flowing down into meadow coats all rocks with lime. Spent a long time here, Polunin collecting and I rambling about. Nothing very exciting geologically, and no birds but the ever-present pipit or occasional snow bunting. Much goose evidence but no geese. One old caribou antler. There is an odd phenomenon on the limestone ledges bordering the rapids of the river, for in high water these are to a degree covered; the water washes out the limestone and leaves the harder particles - bits of mica and garnet, specks of hornblende - and these are arranged in wavy lines of black on the white background, adhering fixedly to the limestone. The various stages of water are shown by the waves, as the river simply washes up against these plates of rock. Any obstruction has its wave line of residual specks about it. Much interesting data on frost action on grassy plains: the frost raises hummocks of mud, and the mosses and grasses hold them together, gradually lining up in long parallel lines or almost geometrical figures. Polunin discovered a total of six unreported plants or grasses for the Canadian Arctic islands. I must write up a sketch of Polunin somewhere. A really remarkable fellow. Future visits to the North, I should first see a botanist, so as to collect for him. Marvelous lichens of all shapes, patterns, and colours. We did not turn back - now at least six miles from coast - until 7:30. Back over trail, taking slightly different course. Afterward discovered to be trail to old mica works. Ate lunch by lake; saw a huge loon: great northern diver. And shadows began to lengthen. Got back to end of lake, or rather the elbow, and struck what turned out to be too far to west. Climbed on top of high ridge and found ourselves peering down, not to the bay but on a large lake. Quite a quandary, as we had not even seen it before. Getting a little late, and sun had set. Standing on this high ridge with the long lake below, two courses were open. Either go to left around the lake or to the right and try to get around what might be an inlet from the sea, as we could not see the end. We took a compass bearing, which showed how far off we were (about $15^{\circ}$ ). The logical way seemed the left, but the illogical, and the compass bearing, indicated the right, though it seemed ridiculous. We took the right, trusting compass over apparent logic, and in short order, a matter of not many steps, I recognised a long slope with my glasses. We were in. This lake of course had not ap- peared on the map. When crossing over ridges that have no distinguishing features and then coming down into a valley, one should be extremely careful to establish a point of departure in the valley and take a bearing on the trail down which one travelled. In returning, always attack the slope from the point of departure. Otherwise, whaleback ridges are very likely to throw one off on either side, particularly when there is nothing to shoot at and one is tired on the return trip. This is an important and valuable lesson. I have never travelled in such difficult country - both as to actual terrain and directionfinding. Oddly enough, I found two caches of fox traps, size $1 \frac{1}{2}$, thrown in little heaps in fairly conspicuous spots. My legs were tired when we finally got to the RCMP Post. I suppose we covered at least 20 miles - a conservative estimate - most of it over broken talus or clinging along gravel-limestone slopes or across tundra and mud. Very tough, and I am very soft. Fortunately found an old plug of chewing in my pack - a great comfort. The wind, which had kept the mosquitos at a distance all day, died down as we entered the last valley, and the bitches descended in clouds. It was 10:30 when we reached the Post. No boats in sight. We opened the door of a tupik, and a woman and baby were sitting next to a little seal-oil lamp, but no men. We at last hailed some Huskies and got a lift out to the ship - I gave them the rest of my cigarettes. About 11:05 aboard and to bed shortly. A fine day and extremely interesting. Lovely country back from the high escarpment of the coast; much rolling, with the jagged gneissic ridges, some almost columnar, appearing rusty and black against curiously rounded smooth white of the whaleback limestone semipeneplanes with the line of green, and the drops into lakes of every conceivable shape and very blue, occasionally flanked with patches of snow. The day was successful both as to general view of the country and specimens. Polunin, though but 27, has a doctorate from Oxford and has worked in the Alps, the Tyrol, Spitzbergen, Norway, and three times in the Eastern Arctic. Never saw a lovelier day anywhere. Nichols delighted with shells - one not before found in Arctic islands but only at Churchill. Others finer than all those he got last year.

\section{July 28 Baffin Island, N.W.T.}

Caught a cold two days ago. Feeling tired today. Finally got ashore and visited post. [J.] Bell, the manager, is one of the largest-bellied fellows I ever saw - gargantuan. Talked with manager of Dorset - [O.M.] Demment - who had a bottle with a gangrenous finger of a native that he amputated. A very soldierly fellow: handsome and aware of it. Is making trip from Dorset to Pangnirtung this winter. Turner went ashore, is staying here. Watched Tommy - Husky police interpreter crack Turner's tremendous dog whip. Bought a little ivory whale from Neilson, the missionary. The ever-present Gillespie was there gathering up trophies as usual. Took some pictures (Fig. 9) of natives and dogs, then back to boat. A fellow with a load of cigarettes and some shirts could trade about anything he wanted. You can see water right through a 


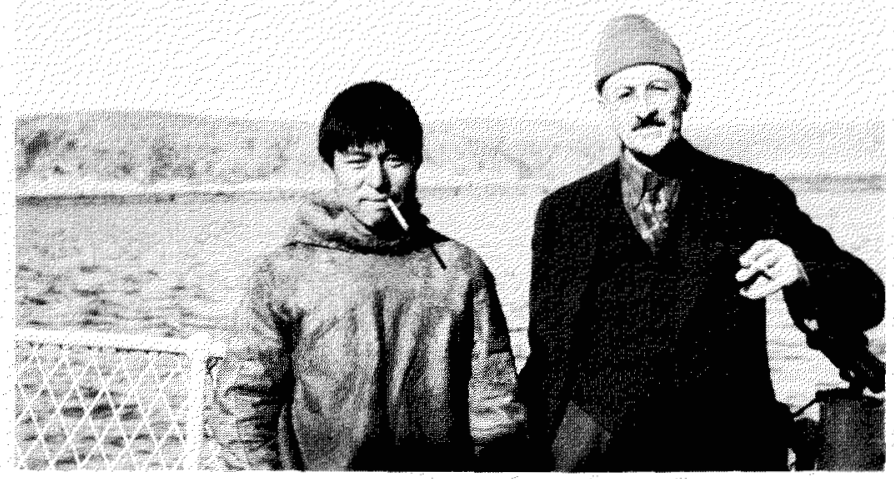

FIG. 9. "A young Lake Harbour hunter and D.A. Nichols"

kayak, looking down through the cockpit. Very narrow paddles, some edged with ivory. Little boys about nine or ten scurry about in kayaks; paddle with arms extended and paddle resting on gunwale of cockpit. Very hot today and little wind. Mosquitos at leave-taking terrific. Wilderspin got off here. Nice lad. Swarm of the beasts followed us out to the straits. Lovely sunset with that curious lemon streak, so characteristic of the north. Overcast at evening, and usual floating tiny bergs. Must send Wilderspin Christmas greetings.

\section{July 29 Wakeham Bay, P.Q.}

Awoke vaguely at an early hour to hear the Nascopie crunching through the pan ice. So sleepy did not investigate much. Quite a sight by breakfast, as we were anchored here at Wakeham Bay surrounded by thousands of contorted figures of pan ice and fragments. Wakeham Bay is on east side of a long fiord. The two posts - Revillon having been long established here and now belonging to the HBC - are located on a grassy wide slope, looking very small and bleak, as usually the posts have been crowded under crags. Much more green and not the craggy outcrops of sheer weathered rock, as is the case at other places. Most gulls yet seen located here: black-backs, herring, Kumlein, glaucous (Iceland?). Went ashore looking like Washington crossing the Delaware. Two old women hobbled down to shake hands. Mosquitos immediately launched their attack. Went with Nichols up back of post to raised beach - cobble - then back through long valley and along lake. Turned northeast and up over high elevation. Could see terrace very well defined on opposite scarp of valley. Took sample of soil at $790^{\prime}$. Crossed ridge down into another wide valley. Horned larks, usual pipits, snow buntings, and eventually semipalmated plover. Nichols came upon a goldmine of his post-pleistocene shells and I some fossiliferous limestone. A considerable stream rushes down through this valley. The shells occurred on the south side, well down the meadow. Once again I spotted the odd shell. Moved on down, and while Nichols took a rest I investigated some Eskimo tent-rings we had spotted on the north bank. I crossed over to investigate, and found considerable error in judgment of distances, as they were much further than I had thought - as is often the case in this country when judging distance. Found an interesting setup. Low terrace just above high tide mark had three distinct and very regular tent rings approx. $12^{\prime}$ in diameter. Second terrace, about $15^{\prime}$ higher, had another single ring of different design, and a third terrace $10^{\prime}$ or $15^{\prime}$ higher presented another, very grown over. Coming back had quite a climb over irregular point, the complex being a micaceous hornblende schist which has cracked up in a spectacular jointing plane display. This is a new and interesting addition to the great rock masses which distinguish the various places we have visited. Coming back along the beach I picked up the stock of a gun with a large brass butt-plate: on the stock was the stamp, "London Armoury 1860" - relic of old whaling days perhaps. Very funny occurrence to Nichols as we passed Huskies' tents. Also story of Gibson and 50 car. lasting until Christmas. Must write in later. Also terrific mosquitos here. Hot day, $62^{\circ}$. No wind until PM.

\section{July 30 Wakeham Bay, P.Q.}

Another lovely day with a fine northerly breeze keeping mosquitos down. Went ashore to look for the old gun stock which I found yesterday, and found it after considerable searching. Was come upon unexpectedly while evacuating by Leechman and the ladies and also a large, evil-looking Husky dog, but managed to defeat all of them by some very quick work. Watched the mass marriage of ten Eskimos - attended by other villagers and their children. These are the only Huskies who seem to take to shawls - very vivid affairs. After wedding we finally got aboard, leaving off [T.C.] Carmichael and Knapp, who was very low spirited about it. The latter is going to Payne River. Took on [J.M.] Stanners, the man here. The man who caught the Baffinland salmon is [Abram] Broomfield the interpreter, who is going out this year. Must find his address. [Allan] Fraser promised to send me a pipe, also suggested possibility of going to Chimo next year. Found a lot of old cartridges on beach. The usual spontaneous cheer as those leaving drew away, and then the waving - waving, waving. So we slowly moved out of this lovely fiord at 4:00 PM and into a vast field of pack ice which had drifted down on the wind. While collecting animal data, I missed the sight of a polar bear and two cubs. The vessel moved serenely on, nudging, spinning, overriding, and slicing through the cakes of ice. Truly a marvelous spectacle to long remember: the ice in a thousand forms, perfectly motionless; the sea without a ripple stretching on, catching the western sun; glistening green, blue, white, brown on every hand as far as the eye can see. After supper saw a pair of walrus, one tusked and one offspring. The RCMP boys beginning to get a little more boisterous with such witticisms as: "Call the ship's doctor, an egg is being laid,' and such. Made a check-up with Polunin on game-cycle situation which I shall develop further. Very clever way the ship is maneuvered through the loose ice, and a spectacular sight from the bow. Took some snaps. No lanes visible, but they work the ice like interference on an off- 
tackle play. If she does not break a piece, it is propelled slightly to either right or left, and then the ship twists slightly to the opposite direction, and through we go. All this is accomplished with no perceptible course altering, just wiggling. Sometimes the bow will come right up out of the water on a big pan before the mass sinks or slowly turns up on edge and slides off. Writing this journal, I can hear the steady throb of the engine and the occasional low noise like faraway thunder roll as we crunch into the ice - and feel the curious sideslip we experience with its jar at the end of it. Mr. Green gave me a piece of dried buffalo meat to consume afield. It is not odd that few diaries are found wherein much introspection or interpretation occurs - that is, journals dealing with any type of doing. After a full day of tramping, or collecting, or field work, your thoughts have been concentrated on focal points beyond yourself and your interpretation of mood, beauty, etc. By writing time you are ready to go to bed. It is very hard for me to make myself write at all, and certainly no more than sketches or notes, which I am afraid I shall never be able to recapture unless by the fire with friends and a glass of rum. I saw some mosquitos yesterday with red heads - looked like a parasitic growth. One of the lads, the interpreter from Lake Harbour, tells me some of the old men still conjure. There seems to be a very sincere anti-missionary sentiment here in the north among the natives, and all traders and apprentices, and scientists. Add among incongruities which always strike one in this country: among the Husky tents, amid a heap of seal and beluga bones, a perfectly good mashie niblick. Dogs all ages everywhere and the usual stench of seal oil. Dog faeces and bones the most common underfoot paving. The crystallised limestone of Lake Harbour is of course PreCambrian, and the float with fossils such as found here Ordivician or Silurian. Saw a sledge komatik of $21^{\prime}$. Out of pack ice and full steam ahead: 10:45 PM. Nichols' Mosquito Dope: 2 eucalyptus, 2 creosote, 3 citronella, \& olive oil.

\section{July 31 Sugluk West}

Busy day. Morning found us coming into Sugluk (West): very much like Wakeham Bay. Long fiords and the slopes with north-tending valley and the precipitous heights at water's edge. Went ashore and again battled mosquitos madly. A fine series of terraces here and one excellent gravel beach. Shells galore. Nichols very busy collecting. Wandered about; usual number of pipits. Also many Labrador Savannah sparrows first time encountered. And a very marked Lapland Longspur in fine plumage. Jet black bib and neck and bright orangey nape patch - much different from pale members we get. This is a small settlement. Some nice looking kayaks. Sugluk means "poor." Maurice, the fine, cultured New Zealander, gets off here. Story about the mad Husky taken to Quebec from Wakeham Bay. A desolate and tiny post for one man to be incarcerated in. Some fine meadows here, two nice streams. Overcast all day with finally a merciful breeze about noon. Chewed on hunk of dried buffalo meat, which I found very palatable. Compact gneiss - dykes examined - some quartz, others quarter feldspar - many intersecting.

\section{August 1 Wolstenholme, P.Q.}

Cracked through miscellaneous ice all night, and by morning we were nigh to Wolstenholme. Approaching Wolstenholme close to coast, most extraordinary sight. The coastline is very high, $600^{\prime}-800^{\prime}$, and a long series of exposed cliff-like faces broken by cirques and small drowned valleys. The faces of the exposed cliff areas are a mass of dyke fretwork - light coloured dykes - quarter felspathic - like lace. Some very large and pink, others creamy white, running in every conceivable direction. The cirques on the side present small hanging valleys, while the drowned cirques gives small re-entrants. Colour varies from dark grey compact gneisses to reddish coarser-grained gneiss, very ferrous-stained, which has weathered and crumbled into a sugary gravel. Nichols says these gneisses are all metamorphic, of sedimentary origin. Wolstenholme, like the other spots, at head of a long $U$ (glacier-scraped and hollowed) fiord with precipitous sides. These fiords are ancient drainage channels to glaciers. Nichols to do some mapping and triangulation here. Overcast day. Innumerable flocks of razor-bills - one guillemot as we came by. Went ashore after breakfast with first boat. A very spick and span post. Bert Swaffield here. Took some pictures of first good old Eskimo ruin - probably Thule. Note extraordinary clean frost cleavage on bedding planes of the fine grained gneisses - giving often a step effect, or terraced, on mountain slopes - contrasting to loose sugary frost refuse of coarsergrained and feldspar predominant oxide-stained gneisses. Must include before I lose record the sign appearing very neatly printed [in Eskimo] at Lake Harbour, which translated means: NO SMOKING OR SPITTING ALLOWED. Gibson uses great deal of rice when tripping. Says gallon of coal oil lasts 14 days when travelling tough. Police notorious as soft travellers as far as quantity of food is concerned. Gibson was in police until '25. Learmonth is now establishing a post at Boothia - last frontier. William Ford tells me that innumerable "Innuit"' ruins are on Coats Island. Island has not been really done geologically or any other way. From Stan Knapp - a formula for Baffin Island tripping:

Haricot beans - soak all night

Add plenty meat, tomatos, ketchup; cook; freeze in sheets, break up with hammer - put in bag

Buns ready cooked, lots of lard to keep from freezing

200 rounds ammunition long trip in game country

$1 / 4$ gallon of oil a day

To get on with trip today - moved on up the long and wide river valley. Quite a little river and wide flood plain, meandering, and with usual steep slopes. Eventually saw Polunin, had lunch, chewed buffalo meat, and left him to climb heights. Attracted by screams of large hawk-like bird which became more and more excited as I climbed the cliff. Finally swooped, or rather dropped at me, and I lost balance and slid down a steep snow patch. Went up again and watched it for a long time. Seemed of falconiae group all right; tail all brown and rather splotchy, even back much the same. Seemed to be a lighter band across chest near neck juncture. Later decided it a black gyrfalcon - though stages between that and grey not clear to 
me. Finally got to top without finding its nest. Moved back along ridge after taking nice snooze on side of cliff. Finally got opposite post on heights and took picture of ptarmigan egg I found in little niche - no apparent nest at all. Slipped on way down and tore out ass of pants. Down in time to make last cargo boat, and at last aboard. Nichols got definite fossil forams at $538^{\prime}$ - very probable at $700^{\prime}$. Nice breeze and no mosquitos, or, as they are colloquially known, flies.

\section{August 2 Wolstenholme \& Hudson Bay}

A truly lovely day; the finest of the entire trip so far. Bright and light breeze. Went ashore after breakfast. Hung around with Nichols and took some measurements of "Tunit" ruins. The Lake Harbour people speak of them, as do the Southamptons, as being small people but very, very strong. The stones in this dwelling, which is 5' deep, are so large as to take on the average 3-4 layers of good-sized boulders - of course chinked in. The sides are then piled up with dirt, and there's a sod covering. Buffalo hides loaded on the vessel, as they could not use them here. Finally came back after getting some tough cloth for my seat, which Mrs. [Alice M.] Tallman sewed in for me. On way out we stopped at grounded tiny berg and I snapped a Brünnich's murre that was squatting on it. Had a broken leg. Said farewell to Nichols and Leechman; have been kicking myself that I was fool enough not to stay with him as he wished, as I would have had an invaluable two weeks of fine practical field work, planetable mapping and such, and could have made the entire trip. Well, that's that. Thinking about Chimo-McKenzie next year - must do it. Rarely been so sorry to say goodbye as to Nichols - a fine fellow. But with losing this opportunity, must push on to Reindeer Lake at all cost and pick up all that I can, turn back for nothing. Huskies brought a couple of rocks aboard for Nichols after he had gone. One quartz fragment was shot through with free copper - chalcopyrites. So there is ore here. As we passed Cape Wolstenholme thousands upon thousands of murres flew about - usually in long strings. The cliffs here rise sheer from the sea $1000^{\prime}$ or more, interspersed with cirques partially submerged. The Digges are barren, rounded islands with the usual cliff-cirque frontal appearance. Lower than mainland. Considerable ice about, though open sufficiently for our passage without hindrance. I must remark again on the placidity of the sea - an absolute mirror without a ripple amidst these floes. Heading into sun at supper, then due south with sun just setting in the sea, coppery and flaming, and the moon full and coppery above horizon in the west. Very sad to lose Nichols. Polunin moving in, O.K. Have I noted that some of the Huskies, unlike the Indians, who are wards of the government, have some status as adult Canadians, pay income tax to RCMP. Will be in at Cape Smith tomorrow morning at this rate. Ford tells me the Huskies called [T.H.] Manning, a geologist at Southampton, "maker of earth," because he was breaking up rocks. Notes should be made on number and character of cripples among Huskies. Have seen some at each stop.

\section{August 3 Cape Smith, N.W.T.}

Overcast and very foggy. Stop-and-go until Smith Island showed up through gloom. Finally got in to this very barren island shortly after lunch. Got ashore with first boat. Explored about. Very different complex here. Not sure the whole story. Seems a dense diabase or trap - some of it bunched up like pillow lava, a greenish colour. Odd country. Saw interesting combat between a duck hawk and a rough-legged. Duck hawk was getting best of it until they both turned their attention to me. The other pair soon joined their consorts. The roughlegged had a high-pitched cat-like meowing - and the duck hawk like a flock of hens, though more rasping. They became very excited. I got close enough to the rough-leg to hear the babies squawking. Wandered about and was given some old artifacts by the post manager. Unfortunately, the doughty Major was around, so I promised to turn it over to Ottawa. One large wooden handled scoop from tree butt, whalebone snow knife, sled runner, and harpoon head. Very old-looking, and knife possibly Dorset. Bought some ivory stuff. At last back to boat. One Tunit ruin on small island entering harbour. Several owls seen here this spring and quite a few lemmings also, but very few last fall. Fox very scarce. Watched the Major act Santa Claus, giving away knives for various stunts. Interested to watch youngsters use sling-shot: index finger slipped in slotted rawhide and whirled about with an overhand motion, and other end released; great wrist snap. Tremendous distance. Had a musical hour this evening with Stanners from Wakeham doing a fine job on the accordian. Roberts some weepy-washy poetry. Polunin lost his knife ashore. The Tallmans got a beautiful steatite lamp from an old woman for a tin of cigarettes. Sugluk natives report 3-toed huge bird track in interior. No mosquitos of consequence, which is quite a novelty. Suppose Smith, like Ottawas and Nastapoka Islands, is remnant of the Keewatin flows. In each locality we have visited, at least one and oftentimes several quite crippled natives have been in evidence. At Lake Harbour a couple of children were afflicted - one youngster scuffing about on hands and knees. The old men seem to frequently contract a rheumatic constriction which leaves them hobbling about or using some sort of cane or crutch. Here was one old fellow who barely was able to crawl about. Amazing, the agility of these who are impossibly crippled. One old-timer, a longhaired, partially bald old man at Wolstenholme whose feet seemed to be either clubfooted or frozen at some time, got about with extraordinary agility. Though we had a $25^{\prime}-30^{\prime}$ tide in Ungava Bay, here tide about 3'. Story at Wolstenholme of Eskimo who went hunting caribou and never came back.

\section{August 4 Hudson Bay}

A day of alternate fog and clearing. A good bit of ice early in the day. Way outside of the string of islands that run along the coast. First day in some time we have been all day at sea without landing somewhere. Polunin and I slept and read most of the time. Saw Mr. [Donald] Goodyear, the fellow who gave me the artifacts, off last night to his lonely post, which he will 
maintain by himself. Nice chap, and I think he was reluctant to go - just a few hours' contact, then the long, long year until the Nascopie calls again. Will be in Harrison tomorrow. Very little comment that I can think of for notes today. A grand debate on this evening, but I don't believe I shall get around to it. The debate was held after supper and I went. Rowdy and quite funny. All the Eskimo conjuring has apparently died out, as well as tattooing. Exceptions - possibly Baffinland in some isolated cases. The drum is no longer seen or used as far as I can find out.

\section{August 5 East Side of Hudson Bay}

Moved only a bit last night. Lying hove to because of dense fog and great pans of surrounding ice. Went on deck with [Constable Richard] Yates, one of RCMP boys bound for Chesterfield, and we heard a very distant sound as of surf breaking. No telling just what it was; probably waves - as now blowing - or outer ice. Today one of complete fog. Laid to all morning until late afternoon: then the old heart of the vessel began to pump, and with the lifting fog we are on our way. Only scattering of drift ice. Read most of day. Edna Ferber's Come and Get It, which I found aboard. Like all romantic tales with tragedy in them, I was disgustingly moved by it. I was just as moved, I remember, long ago by "Show Boat." I wish we would get on to Harrison. Have stopped again owing to fog, and are reported to be about 20 miles off Harrison. The coast is so poorly charted in these parts as to make approaches a matter of difficulty without adequate visibility. Talked with [Bruce D.] Campbell, who was apprentice at Cape Smith, about trapping some lemmings next year. Believe I shall give him [Ernest W.] Hawkes' The Labrador Eskimo, as he might very well get some interesting dope. Very good evening with Mr. Gibson, and later Mr. Cantley. W.G. tells me that Burwash's first year report was chiefly concocted from the Post diary, and he actually did no field work. Talked at length about administration of N.W.T., which is a joke, due to incompetence and political bureaucracy. It costs the government $\$ 23,000$ for the Eastern Arctic Patrol and $\$ 23,000$ for police. Ridiculousness of reindeer job - fact is, they are in a small inland area and cannot be combined with sea life of Eskimo which stretches across the continent. [Reindeer had been herded from Alaska to a $6600-\mathrm{mi}^{2}$ reserve east of the mouth of the Mackenzie, where they arrived in 1933: the purpose of this Canadian government undertaking was to provide extra meat for the Eskimo population.] Legislation of game preserves. Many white trappers never kill any caribou. Two doctors at Aklavik - none over all this eastern area. The lay preacher - C.E., whose wife broadcasted - was made a power, and advocates sweeping changes which have resulted in stupid game laws which, if observed, would lead to Eskimo starvation. Reindeer a mad project. Obstacles: dogs, lack of winter feed, deceptiveness of summer feed in valleys. And what is actually being done for Eskimo in face of dwindling game supply? Gibson says Nellink lamps usually oblong. Blubber pounded on block of ice, then put back of rack, and it drains down into lamp bowl. Has several kettles from around
Coronation Gulf of sandstone bound together with native copper strips. Old fragments of Ross engine used as artifacts. Boothia natives and K.W. natives trade soapstone pots from Back River natives. Bartlett trader \& get-what-can without permit or entry rights. Polunin known as the "weed-snatcher" by RCMP boys. The custom of burying differs, in that articles are not broken but laid on graves, then later removed and miniatures take their place. K.W. natives use large, singleheaded drum with short stick on edge in contrast to Mackenzies, who use long stick. Ridiculous nature of Mad Major always an entertaining matter for discussion. Great peroration to Eskimos at Harrison, translated by Lyall - marvelous. Present padre arrived two years ago with handkerchief, and is leaving with 25 packing cases. Finest dress among Coronation Gulf natives. Priest jumped overboard [into Churchill River] a few years ago after leaving Chesterfield as he had contracted a dose. Indian that jumped out of plane from Pelican Narrows to The Pas [see Downes's Sleeping Island, p. 55.]. Campbell tells me he has had two pet polar bear cubs and observed the same phenomenon in both, viz.: they always turn their heads to the right, and apparently cannot turn them more than half way to the left. Campbell thought this peculiar to just these particular animals until he found by inquiry that the Huskies are familiar with this trait among all the bears. [Campbell would recall his Eastern Arctic experiences in Where the High Winds Blow (1946), which he wrote while a prisoner of war in Germany.] Charlie Stephen has been known to "run" from McKenzie to Chimo in two sleeps - of course, freighting up is a matter of weeks.

\section{August 6 Off Port Harrison, Hudson Bay}

A day of stops and goes owing to fog and difficulty of approach to Port Harrison. Late in afternoon finally picked out beacon, and came long way back up coast to entrance of Harrison. Interesting approach, as islands are entirely different in structure and appearance from the mainland. These islands are capped with the last vestige of the Keewatin volcanics. This has caused a tilt, which throws the long down slant into Hudson Bay while presenting a very steep landward face. The whole thing is columnar (basalt?) in appearance, like the Palisades [on the lower west shore of the Hudson River]. On the mainland there is no sign of this flow - only the now usual granitic gneisses, planed and ground down, with the frostfracturing along the planes of weakness giving the terrace effect which is so characteristic. The hills are round-topped for the most part, and there is nowhere near as much talus and fractured blocks as further north. As we let the hook go in fourteen fathoms, a little sloop came out to meet us, bringing Alex "Sandy" Smith, the post manager at Harrison, and Leo Manning (whose father lives in Arlington [Mass.]) of Povungnetuk, and the usual Eskimo accompaniment - also a padre. Went ashore with first boat, and made short survey after supper. Gneiss very compact and hard, though not particularly close-grained; much pink feldspar in large grains, also numerous small veins and dykes of diorite and some diabase, or trap, of greenish cast. Great deal of glacial 
evidence in way of striation which runs $60^{\circ} \mathrm{E}$ of North (mag.). This a great contrast: rocks have nowhere near the extreme weathering and frost fracture of all other areas - broad, smooth surfaces everywhere, not the crumbled blocks so evident in other places. Country also is rather low-lying and rolling. This quite an establishment; many native boats, Revillon and $\mathrm{HBC}$ with several small houses, a tiny church painted the same faeces yellow as at Lake Harbour. I like the story of the post manager who used to ring the church bell to summon the boys to a poker game. RCMP Post - Berwin going here. Sandy beach and long shoals. Flora more prolific: several different flowers and profusion of purple low flowers resembling sweet peas. Pipits, snow buntings, semipalmated plovers abundant. Great profusion of post-pleistocene shells of large size. Enormous macomas and many pectans. Rambled about, and although a strong breeze from north, plenty of mosquitos - though they are reported on the wane. This of course is the post where one of the Leith brothers [C.H. and A.T.] spent the winter; must read that account again, now that I have visited the spot. I believe it is called $A$ Winter and Summer on Hudson Bay [Madison, 1912]. This is a great spot when there's a good year on foxes. 5000 have been known to have been shippped out of here in a good year! Dwarf willow more abundant here then elsewhere. Some fine boulder terraces, and pebbles and boulders are far more rounded than the angular ones of other points. I suppose these would be boring details to anyone who should read this, but it will bring back the picture to me some day, maybe. I think I will send this record out at Churchill, so that if anything happens to my outfit or me between Brochet and The Pas, something of value will be left.

\section{August 7 Port Harrison, P.Q.}

Due to information from Post apprentice, decided to try a little fly-fishing. So walked up stream to first chute and tried eddies with no result. About noon Husky appeared and took me across to other side. Could see trout, but they were very finicky and would take nothing. Tried everything, but wind was so strong upstream I could not cast at all. Husky's name Elishee Apik - Little Elijah; there are three of them, Little, Medium, and Big Elijah. Tried everything, and at last got to a sheltered spot and with green bucktail took two. Then four more on a Dr. Breck. Fine fish, about $1 \mathrm{lb}$. of them. On way back to other side broke shear-pin, and we had very exciting time getting across. Great conversation with Elishee/Elijahsee consisting of three words: "ecalug" = fish, "manee" = there, and "eee," which means anything. Elijahsee very obliging as to information, as everywhere I pointed he said "ecalug," Fine afternoon. Walked back to post and had supper there with Smith, Cantley, and Gibson. Then back aboard. Came back on cargo boat, and it was very, very cold with stiff wind blowing in from Bay. Don't know when I have been more chilled; this Aug. 7th! Gave Elijah rest of cigs.

\section{August 8 Port Harrison, P.Q.}

Left early for fishing, using light $7^{\prime}$ Hardy. Fished niche with Dr. McArthur watching - took two fine fish immediate- ly. Later on took four more at various points. Lost several, owing to hooks snapping at point when ticking rocks. Tallman appeared, and we found a picnic in progress engineered by Captain. Tasted fine, particularly bottle of beer. More intrigued by Husky eating chunks of meat from pail. Others fishing with pork rind caught two. Went off after feed, further upriver. Fishing improved. Ran across interesting steatite outcrop, used for time without record as quarry for kettles and lamps; many pitted depressions, one blocked out in rectangular form. Some fairly recent, showing chisel marks. Name of this river the Inukshoak. Fine fishing finally located in large, foam-filled eddy at foot of third drop. Polunin came along and managed to get one fish. I took a total of 14 , making 20 for day. One a long, thin lake or grey trout, very curious thin, forked tail - yellowish green with oval spots. Took one large fish, $1 \frac{1 / 2}{\mathrm{lb}}$, final catch. Lost fly at last and quit. No wind today and mosquitos were perfectly frightful. Swarms. Not bite, but constant biting is the annoyance and agony of them. Almost dark by time we got back to RCMP post. No one there, but at last hailed some Huskies who took us out. (Gave them all cigars and my lunch - which brought forth chorus of “'Eeees."') Found out on getting aboard I had missed a Husky "Field Day" put on by Captain. Few things more humorous than Husky running. Elbows straight out, and quite on his heels. In racing, the whole crowd pile up when rounding a corner, and much clawing and scrapping to get around. Only other person to fly-fish this river was Sergeant Wunch (?) some years ago. Everyone had trout for breakfast. Note: enclosed menu appeared at our table at breakfast with my trout appearing. Also gives indication of how royally we feed here.

\section{August 9 Port Harrison, P.Q.}

Fine clear day with fresh land breeze blowing. Went ashore with Polunin, and we collected shells from sandy bluffs below RCMP Post for Nichols - got a great horde. This a wonderful place for these post-pleistocene shells. Some huge specimens of macoma, peclaus, and truncated macomas. Mosquitos in abeyance owing to stiff breeze. Left so hurriedly as to miss lunch. Very hungry, and at last got to Post and had glass of Scotch. A fine clear afternoon, but felt rather tired and listless. Rough-legged hawks seen. Polunin brought in lemming which I am sure is a bog-lemming or lemming-mouse; synonymous terms, may be either Ungava subspecies or Labrador - probably latter; in any case, a very rare species. Long talk with Campbell, apprentice here; must send him mouse traps. Great joy, for bought caribou artige from $\mathrm{Mr}$. Cantley tonight. Picked out a beautiful one, quite heavy, and nicely trimmed with white belly hair of caribou - also fringed. He did not tell me the price. They had five in a bale (Fig. 10), but as natives killed a good quantity of deer about 40 miles south, not all needed. These from Western Arctic, Chesterfield or Repulse. Same type as King William Island natives wear, a marvelous thing - brand new and in fine shape. Wonderful sight this evening. The afterglow which lasts so long in these latitudes in the NW - a wonderful, high-reaching pale aurora - and a brilliant gibbous moon. Aurora seemed more SW than north. 


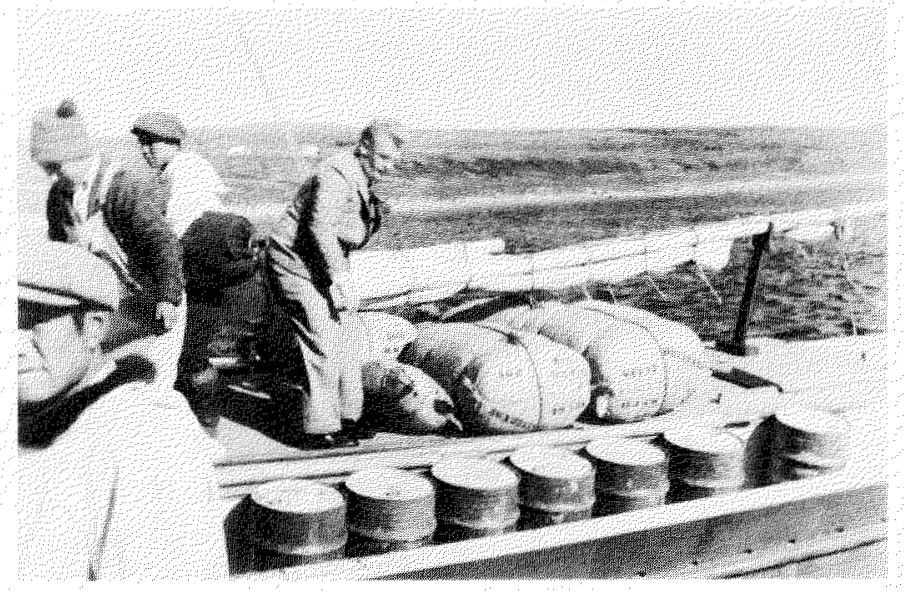

FIG. 10. "Loading fur, Port Harrison"

Brief chat with Alex Smith. He was at Chimo years ago. Tells me of seeing old Naskapi man with deer's head skinned out as hood of dickey - ears and all. Lost fine chance for information here. Leo Manning, manager of Povungnetuk, been in country 17 years. Came in at 17 himself - brother caddied at Arlmont [Massachusetts]. Much of time on Baffin and great baseball fan. Story of his old housekeeper and Mickey Cochrane [the Philadelphia Athletics' and Detroit Tigers' great catcher]. Might contact Smith again on Naskapis at Chimo. This evening's display a fitting farewell to this, my last port of visit before destination and finale of this Eastern Arctic trip.

\section{August 10 Hudson Bay}

Fine fair day, wind fresh westerly. Weighed anchor about 4 AM, and away for the five hundred mile run across the Bay to Churchill: "good byes" will be the next in order. Never have I had a month go like this one, and never will I so regret leaving a ship as this one. Must make the northern end in another year - but "the other year" never seems to come. [It would: in 1937 Downes joined the Nascopie in Churchill on 13 August, and left her in Halifax on 27 September.] Saw flock of 5 black guillemots alight near vessel this morning; very bright red legs and feet, and very sloppy landers. Couple of Husky women at Port Harrison really quite attractive-looking. Revillon post is of course being consolidated and the Rev. man is going out. Eskimo Christian names most amusing: Cornelius becomes Cornusleesee. Indifferent day as far as activity is concerned. Sleeping, eating, and chatting being sum and substance. Moving through loose pan ice at nightfall. Had nice chat with Gibson on possibility of spending a year at King William Island or on Boothia. Must get him to order me down a full winter rig from Western Arctic. The Mad Major dropped in to chat this afternoon with the usual line. Rather interesting dope that owing to confusion of Eskimo names - difficulty of spelling, missionary Christian names, etc. - they are now beginning to fingerprint them for departmental records. The stupidity and gross error of [Bob] Bartlett on Karluk on the Stefansson Wrangel Island Expedition: in Western Arctic it is essential to keep out of the polar pack and to hug shore inside of stranded ice. To this end, old [Capt. C.D.] Pedersen of the Canalaska Trading Co., one of the canniest old skippers in Western Arctic, ballasts and swings weight on his vessel (such as filling tenders and lifeboats with water) so as to heave her over on her side for less draft. Fourteen feet about limit of draft for vessels in those waters. Could do Western Arctic trip on a couple of thousand. When I get back, I must work like a fiend on physiography, boreal fauna and ornithology, geology and petrography, cartography with triangulation, and more archeo- \& ethnological work; also something on paleontology and shells. Have I noted bumblebees at Lake Harbour? Long talk with Dr. McArthur about general topics. Natives of Cape Smith-Harrison area use moss sets for foxes. Baffin (Lake Harbour) often use paper - of course, snow is standard set. Should record here, before I forget, one of those tragedies which are so unimportant to any but the victim. Allan Fraser - before mentioned - young fellow more or less inspector for Ungava Bay and stationed at Chimo, was engaged to be married to a girl from St. John's stenographer in office there. Sent him endearing messages all winter, and she had booked passage on the Nascopie to join Fraser when vessel got into Burwell. Radio messages stop in April, and everything fine. Just before Nascopie left, with new furniture, wedding cake, etc., etc., the girl notified Mr. Cantley she was not going - and in fact had just married somebody else. Fraser could not be notified. Came out in Koksoak to meet Nascopie, and supposedly, the young bride to be - instead of which, Mr. Cantley had to break the news to him. What a bitch.

\section{August 11 Middle of Hudson Bay}

Pushing through pan ice all day with a very strong westerly wind. Some fog, and at such times we are inclined to slow down considerably. The ice looks very old and rotten. It is always encountered here in the Bay - drifted south by strong winds, only to drift back again. Remains all summer in some degree or other. A day of little or no activity. At supper, we had passed well through the ice and the strong wind had set up quite a swell. This coupled with the first appearance of tripe at the table, caused some uneasiness among several passengers. The good weed-snatcher, working among his plants in his new quarters - formerly in hold, now in cabin aft - felt rather queasy. Have I noted his rather unique habit of wearing two pairs of pants with the optimistic idea that one pair of holes in the seat will not coincide with the holes in the next pair? Long gabfest over everything, all of which we soon reduced to the "utterly fantastic," our pet phrase of the moment. Long chat with the Mad Major. A very dreary talk on merits of baseball over cricket. Expect we will be in Churchill Thursday morning. Constable Yates, due to go back in to Chesterfield, dropped in; a mighty attractive fellow. Must not forget to send this out. Started to write letter today, but gave up. It is very hard to write. There is too much - and too little. Those you write to are not interested in what you are, and you cannot find enough that they may be interested in to bother writing. From the day we pushed off from Pier 6 in Montreal, 3500 miles will 
be our tally to Churchill. Polunin wants me to go to Greenland with him next year. Which will it be: Greenland; up the Peace, down Liard \& Mackenzie; King William Island or Boothia; Fort Chimo to the Gulf? All attractive. And then the next year? Must not forget Gibson's wonderful tale of the shooting of the cuckoo clock with Godsell asleep.

\section{August 12 Churchill}

Fine clear day with strong westerly. All trace of ice gone, and the air positively balmy. Very odd to have wind feel warm. Bowling along at fast clip all morning; feeling very low about leaving vessel and so many friends. A marvelous experience to be in a group of people, all of whom know so much about such a number of varied things. Leo Manning is to a degree typical of the man who has really been in the country a long time. To some of these, the coming of a boat like the Nascopie is actually a nuisance - disturbs a definite routine, and they don't like it. Manning is the finest linguist in the region. Should send him some baseball magazines. Natives at Povungnetuk very difficult, according to [W.G.] Calder; one stabbing, and only cases of stealing. Slipping along at better than ten knots; a lovely, lovely blue day: high, diaphanous cirrus clouds. About 4 o'clock a ship was sighted off the port bow. A great sensation, for to sight a ship in Hudson Bay is quite an event. She turned out to be the Firby, loaded down with grain from Churchill and bound back to England. A few herring gulls began to appear. Then the low, flat shores, the west side of Hudson Bay; then, standing high and bulky, the huge grain elevator. A few Arctic terns appeared - a loon nearer and nearer - wireless tower - red-roofed RCMP post - houses - trees - railroad cars - Fort Prince of Wales on the right - the Ocean Eagle and a dory - the pilot. Journey's end. We came alongside the Wentworth, a freighter discharging barbed wire and glass for Saskatchewan and the west. Grimy, curious faces watched us. A few miserable Chipewyan tents cluttered the shore amidst a junk heap of rusted machinery. Not a sentimentalist, but an almost physical shock of ugliness. Smoke and oil on the water. Faces just blank - no smiles like Huskies - noise of winches and steam. I wanted to go back right then and there. I should like to be able to translate my psychological state at this moment, but impossible. But I never have felt such a sense of ugliness and disgust. It was just 60 'clock when we got in and tied up alongside. The winches hammered fiendishly until midnight. The mail began to arrive - bags \& bags of it - mostly going north. Went down to Chief's cabin and dashed off some letters, first written since Montreal. Watched them unload for awhile. The weedsnatcher had a tremendous sack of mail; most extraordinary Poland, Spain, Russia, England - amazing. Twelve boats expected this year. The record is seven. Felt very low, but after a while quite cheered up. Low about leaving vessel. Seems very hot and stuffy. Finally to bed very late. Calder, who was at Chimo and Sugluk, gave me some marvelous stone arrowheads and a tiny ivory whale an old woman brought in to him from some of the Tunit ruins on islands off the two Sugluks. Very definite Dorset culture stuff in some of it. Marvelous ground slate arrows and harpoon head - this latter Thule culture. Want to get into bush as soon as I can.

\section{August 13 Churchill}

Still at Churchill with bunkers taking on coal. Wandered about this miserable town in AM. All refuse of construction. Millions put in this politicians' dream. Very hot - seems unbearable. Not much to see. All kinds of shore birds here: western willets, greater \& lesser yellowlegs, pectoral \& western sandpipers; least \& northern phalarope. Also common tern. Savannah sparrows. Very odd erosion on dykes of volcanic diabase along shore. A tour of rusty scrap iron and tarpaper bunkhouses. Many mosquitos and sandflies - brulos. Some went over to the old Fort Prince of Wales, but I believe I'll wait and go over with Polunin. Blistering day; beastly to be in the heat again. Met [R.A.] Talbot, District Manager of Saskatchewan, tonight and he tells me everything is all set for the Brochet hop. He is going in by plane and I may see him up there. Big time coming Sunday with excursion from Calgary due. Once a year, great excursion from western Canada so prairie yokels can see their fine new seaport. Calder is going back to the old country and will be going down on the train. Also Doc McArthur, so ought to have a gay time to The Pas. Saw some Arctic Fox hanging in store for $\$ 32$, poor skins, too. Loaded with dirty shirts; believe I'll throw them away and get some new ones. Lichens on land side of rocks like Cayenne pepper sprinkled about.

\section{August 14 Churchill}

Busy; a fine day. Polunin and I, owing to arrangements by Mad Major, were able to get away from the ship at 7:30 AM in the harbour bumboat, the "Cruiser," and were taken across the river to the Fort Prince of Wales side. Made arrangements at cook shack for lunch, and then walked up to Sloop Cove. Found it with aid of map at last. Tiresome to speak of mosquitos \& flies so often, but this was a new experience. Swarms of blackflies and a sort of pale sandfly in hordes as we went throught the long grass and muskeg. A constant cloud. You can hear them striking the brim of your hat like sleet. They get packed so closely that they cannot get out of the way, and you literally bump into them - as they get into your eyes, nose, and mouth. Polunin quite swollen in short time, but I must be getting tough, because I did not swell up much. The constant brushing them out of the eyes and face is a monotonous madness. Finally found the cove. Here the names of ancient HBC servants, sailors, etc. are pecked in the rock, looking as fresh as if done yesterday. And of course, there in single majesty, with neatness and artistry, 10" high, stands: [Downes copied Samuel Hearne's inscription]. Many other names and several old ring bolts. This tiny cove is quite dry now, due to breakwater and barrier beach. It was much more thrilling to look for and find this myself than to be led to it. Lowest name, J. Horner 1746, about level of present high tide. Also man hanging from gibbet [John Kelley]. Extraordinary how fresh these names appear in the grey diabase. Some less important are 
overgrown with lichens. A couple of Chip tents in back and dogs. Polunin went back to work at tree line. Trees here are spruces about $5^{\prime}$ high. I worked around rocks, and was spied upon the whole time by two Chip women: seen by Polunin, but not by me. Chip dogs chained up and quarrelsome. Saw beautiful early-ended toboggan, much heavier than Montagnais. Rain stopped. All kinds of shore birds. Finally got back to cook shack, and had a marvellous feed with workmen from Fort - who finished meal in 14 minutes flat. Polunin at last showed up and enjoyed fine meal as much as I did. Inspected old Fort, now in process of reconstruction. Very complete, and quite imposing. Entrance finished in grey dressed stone (not diabase here locally quarried), guns set up. Many of guns lying about as they were overthrown by La Pérousse. Sides and buttresses of undressed, huge blocks, and innumerable beautiful bottle fragments litter the place. Extensive establishment. Big ditch in front. Many cannon balls of three calibres, old sheet lead, etc. A large Wood Buffalo skull outside fort - workman told me four were found in woods. Rather important specimen, it would seem to me. Seems a shame that restoration - like all restorations - makes everything look so new; and stone weathers very, very slowly in these parts. Walked back, then went to Sloop Cove by boat. Bloody shame that anyone can possibly have gall to scratch their measly names in next to such as Hearne, Taylor, Wood, et al., but such is the case. Finally returned to Nascopie. Climbing aboard an amusing incident. The toilets flush out the side of the vessel, and while Doc McArthur was waiting to climb ladder one of the vents let go and he was liberally doused. After supper a walk about the town, boys expecting to see the fair Ethel in the General Store, then about, to finally come back. Talked with Mr. Gibson, and he gave me as part-

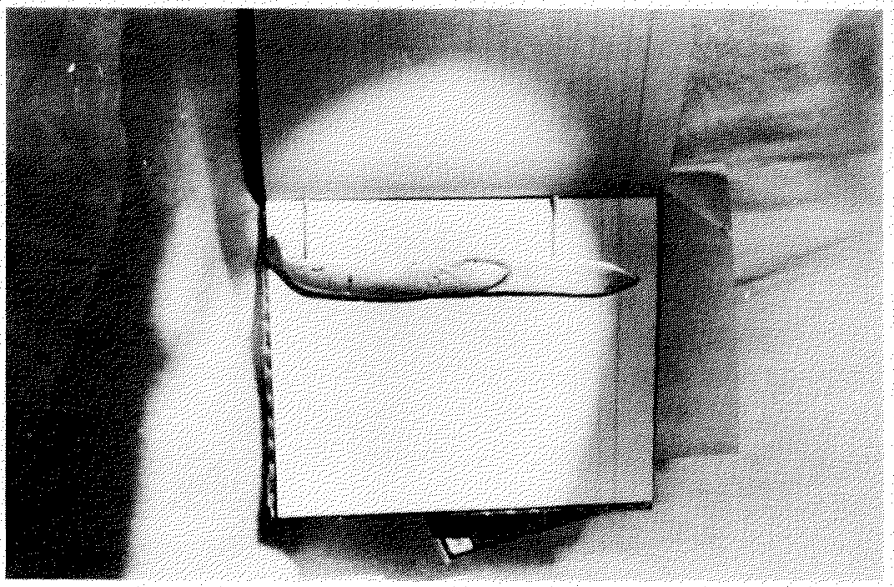

FIG. 11. "The knife from King William Island"

ing gifts the knife (Fig. 11), rusty and grease-covered, picked up by half-Husky wife of engineer on shore of King William Land - very likely a Franklin Expedition relic - and a copper sealing harpoon head brought in by Boothia natives, made from piece of the John Ross engine which was thrown out on the beach of Boothia. One of the most extraordinary of all N.W. Passage sagas was this trip, which led to the discovery of the magnetic pole, and to five years' incarceration. To this day natives still use articles made from the old engine. Kudliks have been made from boiler plates plugged with lead in rivet holes. So this little copper harpoon head, beautifully done, is an actual piece of that master of argument and folly, the old engine of the famous Victory. It is quite impossible to describe how absolutely ecstatic I am with these two relics of a century. or more ago. Gibson, who ranks as a Chief Trader in the Western Arctic, may possibly go back to his district in two years, and when he does, I plan to go with him. As things line up now: Leave next summer on Nascopie for Burwell. Go to Chimo on Koksoak; go up with Stephen and freight to Fort McKenzie. Do natural history there, and work on Naskapi material; stay in at McKenzie until midwinter, then walk out to Seven Islands with mail, whole length of Labrador peninsula, which would bring me out in spring of 1938. Back to States. Somehow must raise enough money to finance trip in to King William \& Boothia if Gibson goes in there in '38 or '39, to work with him on the Franklin remains at Starvation Cove \& natives on Boothia. Dreams? Maybe, but very feasible if pushed through. $\$ 2000$ for Western Arctic. $\$ 25$ by January to Gibson for full winter caribou outfit: pants, socks, footgear, double artige, sent down from Western Arctic.

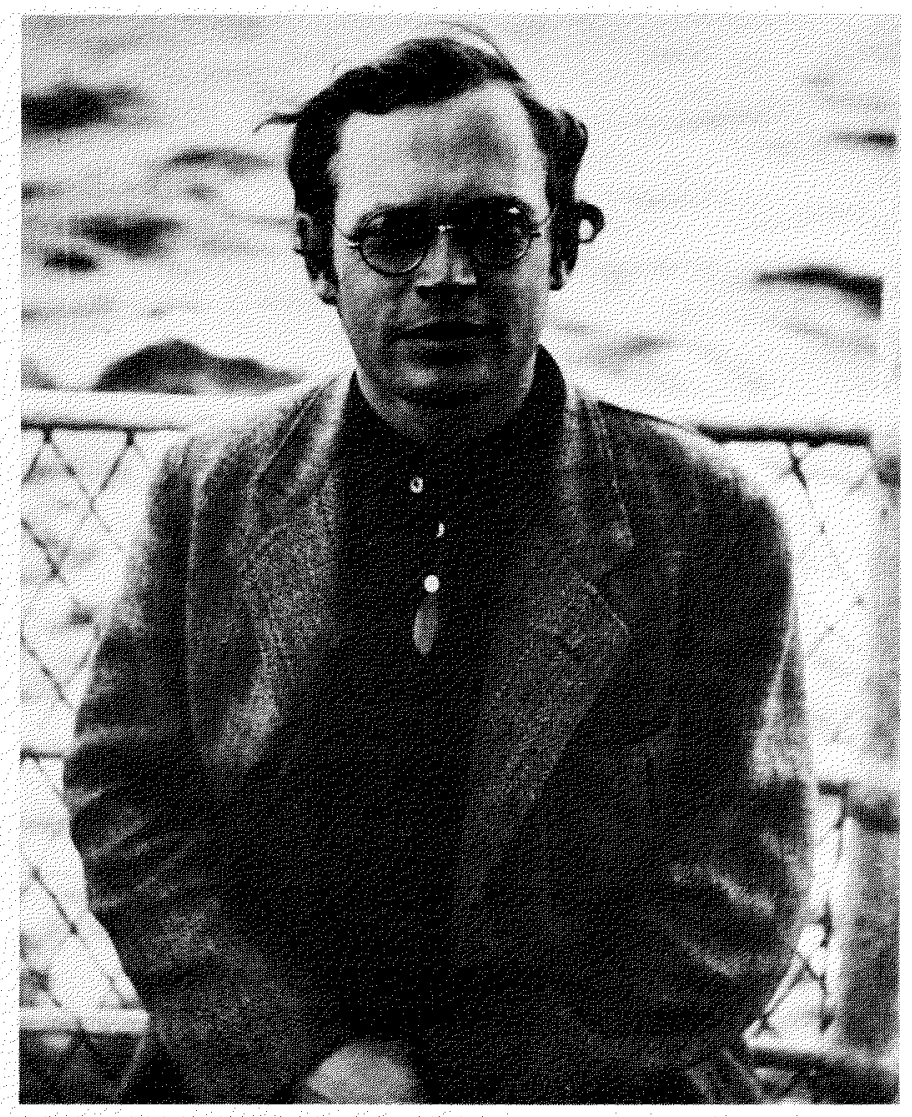

FIG 12. Prentice Downes aboard Nascopie. Photo Richard S. Finnie

\section{August 15 Churchill}

Spent morning bringing this journal to a close, as this evening we move ashore to make room for the new arrivals. So this voyage ends - a new trip about to begin. I hope that I may have a chance to gather scattered fragments together, for my 
head is buzzing with what is here but briefly mentioned. This winter should be a busy one with this material in hand. Goodby, old Nascopie and your company of so many friends.

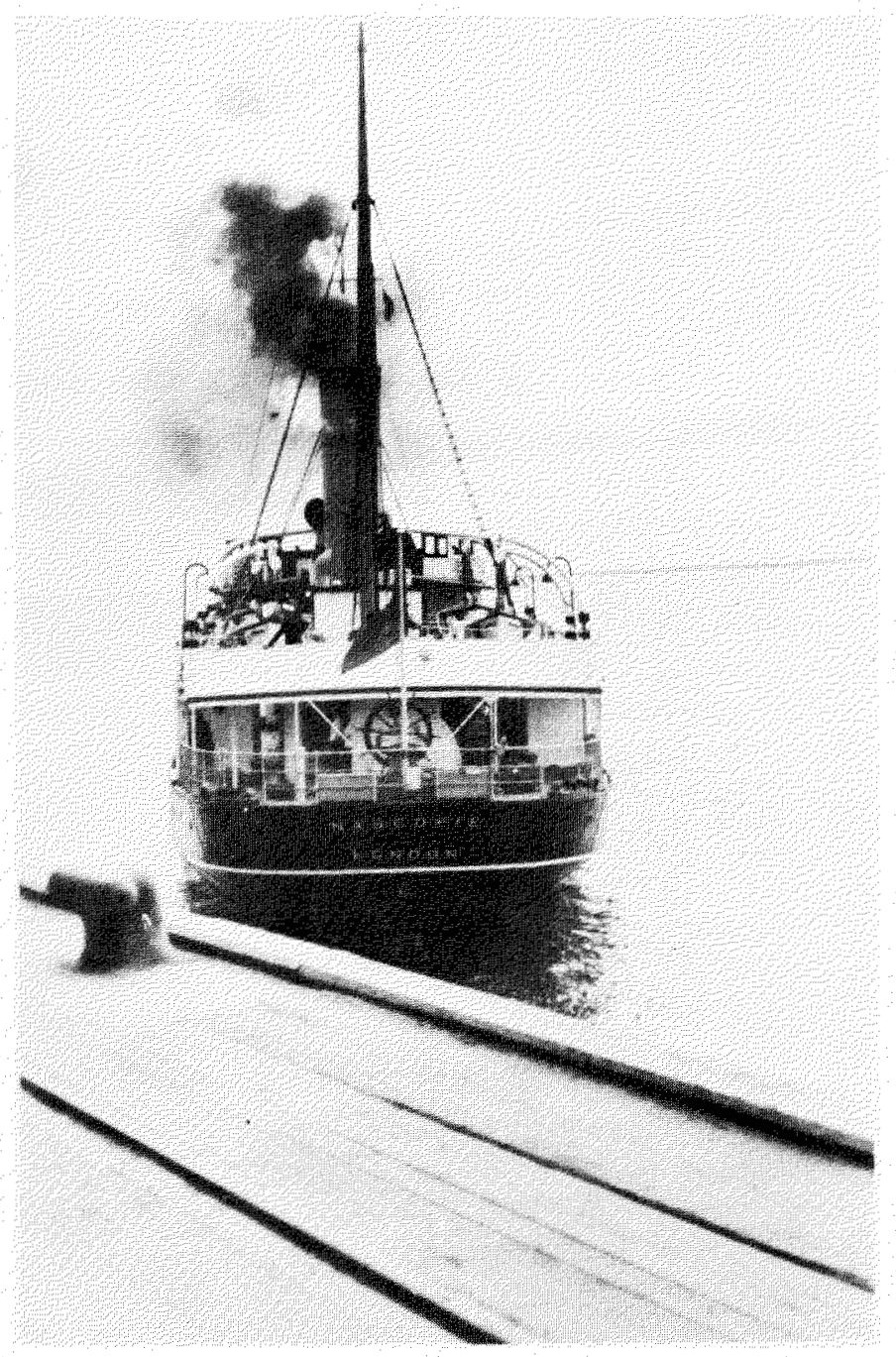

FIG. 13. "Nascopie departing Churchill"

Editor's note: Downes arrived by rail in The Pas on 19 August. He flew in to Pelican Narrows on the 23rd, and two days later set out for Brochet by canoe with a Cree companion.

\section{REFERENCES}

ANDERSON, J.W. 1961. Fur Trader's Story. Toronto: The Ryerson Press. $245 \mathrm{p}$.

ANONYMOUS. 1935. The Arctic Patrol. Canadian Geographical Journal 11(5):VI.

1936. Nascopie sets out on arctic voyage. The Beaver 267(2):52-53. 1936. The fur trade: Ungava district. The Beaver 267(2):63-64.

BURGESSE, J.A. 1951. Seven Islands, P.Q. The Beaver 282(June):30-33.

BURWASH, L.T. 1930. The Franklin Search. Canadian Geographical Journal 1(7):587-603.

CAMPBELL, B.D. 1946. Where the High Winds Blow. New York: Scribner's. $215 \mathrm{p}$.

COCKBURN, R.H. 1982. Prentice G. Downes (1909-1959). Arctic Profiles. Arctic 35(3):448-449.

COPLAND, A. 1942. Paddy Gibson. The Beaver 273(June):7.
DE PONCINS, G. 1941. Kabloona. New York: Reynal \& Hitchcock, Inc $339 \cdot \mathrm{p}$.

DOWNES, P.G. 1943. Sleeping Island: the Story of One Man's Travels in the Great Barren Lands of the Canadian North. New York: CowardMcCann, Inc. $296 \mathrm{p}$.

EVANS, A.R. 1935. Reindeer Trek. Toronto: McClelland \& Stewart. 269 p. GIBSON, W. 1929. The "Victory" relics. The Beaver 260(3):311-132. 1937. Sir John Franklin's last voyage. The Beaver 268(1):44-75.

GODSELL, P.H. 1934. Arctic Trader: An Account of Twenty Years With the Hudson's Bay Company. New York: Putnam's. 329 p.

HOURDE, R.N. 1937. Reindeer herd. The Beaver 267(4):26-29.

KLENGENBERG, C. 1932. Klengenberg of the Arctic: An Autobiography. London and Toronto: Jonathan Cape. $360 \mathrm{p}$.

LYALL, E. 1979. An Arctic Man: Sixty-Five Years in Canada's North. Edmonton: Hurtig Publishers. 239 p.

MARRIOTT, R.S. 1940. Canada's Eastern Arctic Patrol. Canadian Geographical Journal 20(3):156-161.

McKEAND, D. 1938. The Annual Eastern Arctic Patrol. Canadian Geographical Journal 17(1):37-38.

O'BRIEN, J.S. 1935. Alone Across the Top of the World: the Authorised Story of the Arctic Journey of David Irwin. Chicago: John C. Winston Co. $254 \mathrm{p}$.

STEPHEN, C.N. 1941. Koksoak River Brigade. The Beaver 272(June):36-43. TODD, W.E.C. 1963. Birds of the Labrador Peninsula and Adjacent Areas. Toronto: University of Toronto Press. 822 p. 